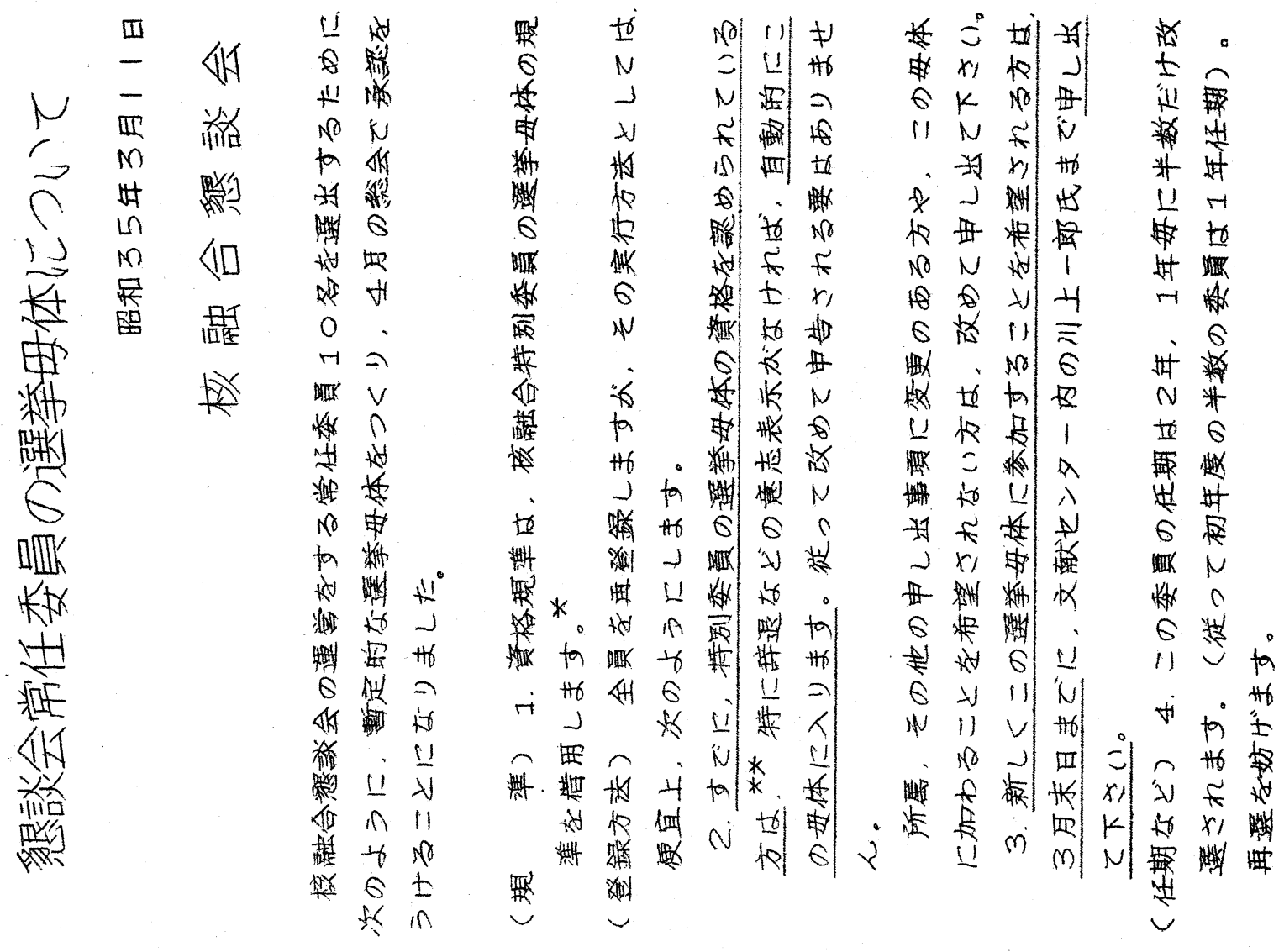




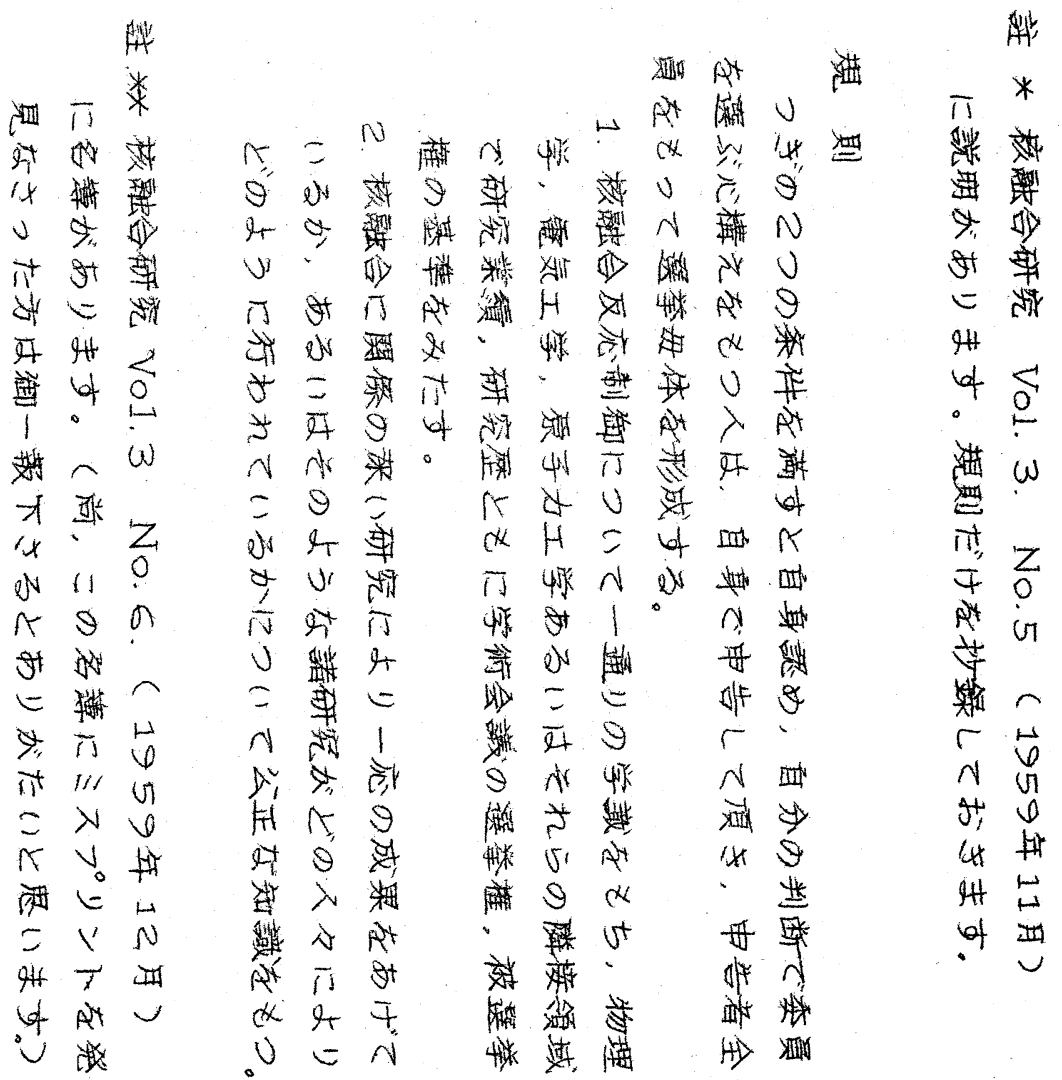

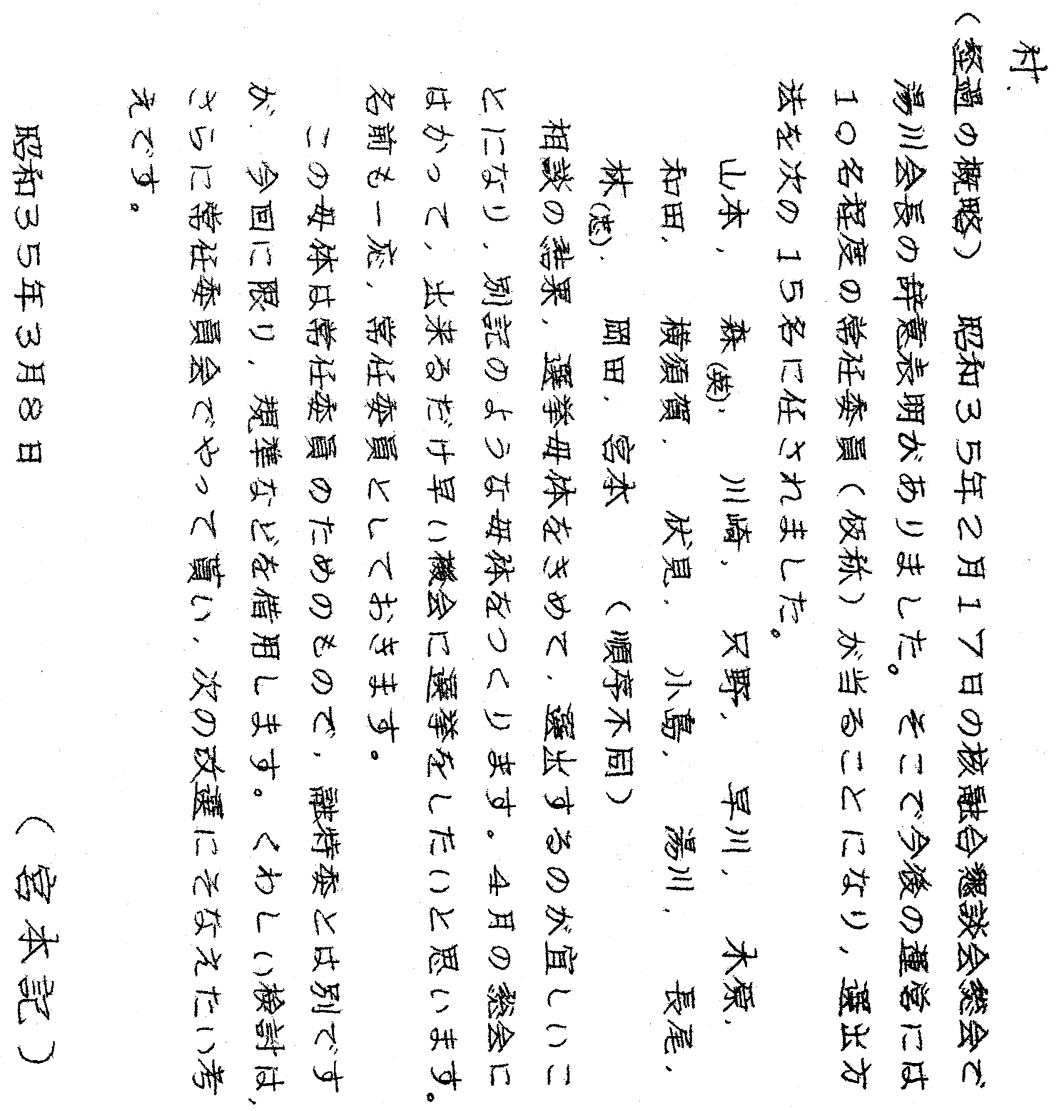


昭和 34 年度ブラズマ測定研究会のまとめ

I 探 釷

(a) Langmuir 和よび複挆針

1. 高温プラズマにおける钉極測定の2.3の問題

名大工 奥田孝美、山本賢三

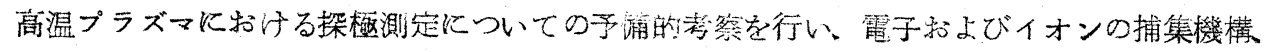

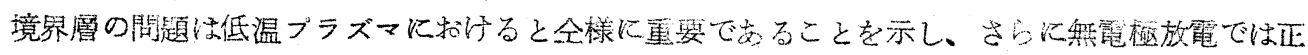

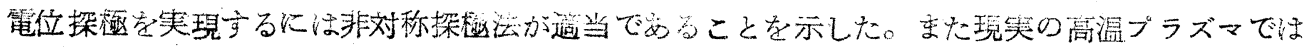

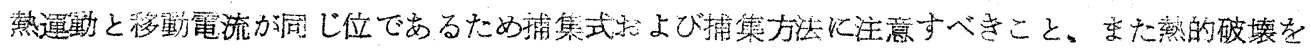

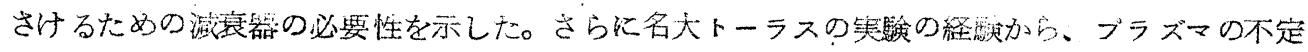
定性岁るいは国有の振動による障㕩のだ、普通の手段ではかなり湘定は困難で安ることが判つ たo

2. プラズマパルス偨針法の2.3について

阪大工山中千代衛。和画弘名。山村豊

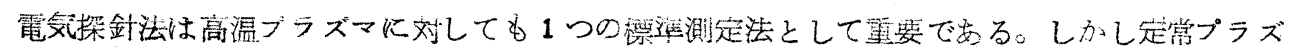
マに対してはともかく過渡プラズマに対してはシースの応答に問題が女りこの辺の研究が必要で ある。

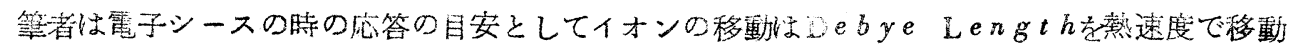
する筈であるからブラズマ周波数で見当づけられることを主張した。

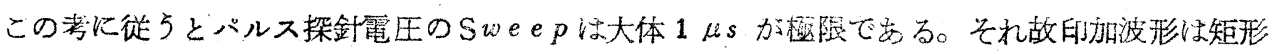
波より三危波の方が有利であることが分る。

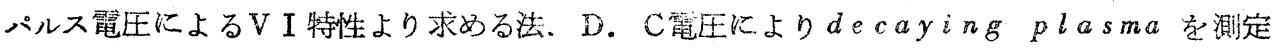

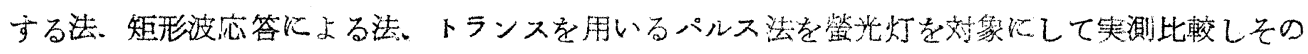

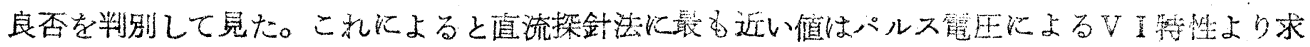
める法の時得られ、ついで $a$ e $c$ a y ing plasma 测定よりの外䀯、矩形波応答による法の㮌 
小島昌治他

で女つた。トランスによるパルス印加法はンエライト磁心を用いる方式が良好のようで女るが末

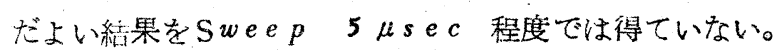

\section{3. パルス探針法車大理 玉河元、藤田順治}

高密度過渡ブラズマの電子温度、ブラズマ密度を測定するためには充分短い時間内に 1 回の測 定を完了しなければならない。そこで過渡ブラズマに対する探針測定法を確立するため、高密度 定常プラズマ (水銀蒸気) に対してパルス探針法を適用しての可能性を吟味した。

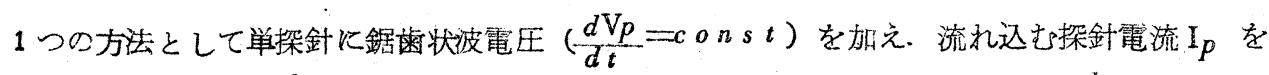
ブラウン管の $\mathrm{Y}$ 軸に、 $\frac{d I p}{d t}$ を $\mathrm{X}$ 軸に導入して得られる図形の勾配 $\mathrm{I}_{p} / \frac{d I_{p}}{d t}\left(\propto \mathrm{I}_{p} / \frac{d I_{p}}{d_{v}}\right)$ から電 子温度を、折曲り点からブラズマ密度を且視し得る簡便なお法について発表した。

4. 大電流放電ブラズマの探針測定東大理 玉河元、藤田順治 为 1 回研究会で発表したパルス拱針法を実際に值線状放電管の過度ブラズマに適用した結果。 定性的には放電初期に比較的電子溫度の高い状態があること、プラズマ密既は大体放笔々流に比 例していることなどはわかるが、放笔そのもの」振動や雑音のため確実な情報が得られず、従つ て測定時間をるつと短かくする必要が岗ることなどを述べた。

5. 過渡探金特性東大理 玉河元、藤田順治、足立主三 探針䉓区を早く变化させた時の探針電流の応答からプラズマやシースの挙動を調べ、特にェレ クトロンシースの電圧に対する追従がイォンの潖性のため遅れることなどについて解析した。

\section{6. パルス挆針とプラズマ応答}

京大工 大谷泰三、阪口忠雄、板谷良平、古谷洋一郎

矩形波パルス探針法の精度と印加パルスに対するブラズマ応答及びパルス伝播特性の研究を行 なつた。

矩形波パルス挆針法は矩形波パルスをCーRを介して探針に印加し探針電圧の応答からプラズ マ諸量を求めようとするものでるる。この方法は静的な探針特性がパルスにも適用されるといる

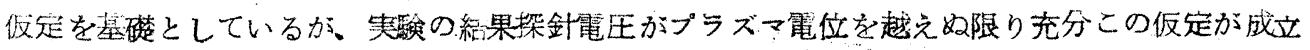
することが判明した。従つてこの方法は電子温度及びィオン電流の測定には極めて簡便かつ有効 
昭和 34 年度プラズマ測定研究会のまとぬ

である。

探針がフラズー篦位を越えると応签は静特性からずれる。またこれに伴なつてブラズマ中をパ ルスが伝播する。静特性からのずれは探針の電子捕集が静的平衡の場合より大きくなる為え起る ものである。

またパルス伝播特性については。検出パルス波高はプラズマに注入されたパルス電流の大きさ に依存し、波形の立上りは印加バルスより遅延する。この結果から伝播パルスは電子の舆常捕集 によつて生じた正の㒰間電荷によるものと考えられる。

昭和 34 年電気関绿学会関西支部連合大会豫稿 P 194 参照

7. 低温グロープラズマの応答時間

東北大工 柴田昭太郎、八田吉典

板谷、玉河、藤田等の諸氏によつて研究されているパルスによる探針測定法について現在間題

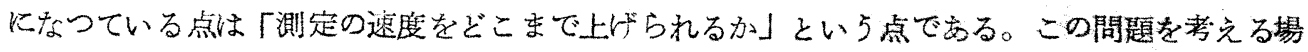
合、現在ではバルス電王は総てイオンシースにか」り、ブラズマには影響がないるのと考えてい る。

しかし、これは理想的な場合で、実際にはバルス電压の一部がプラズマに加わることもあり得 るわ忛で要るから、このよ5な場合にどんな現象が抗こるか明らかにしておくことはバルス探 針法の現象を明らかにする上に必要なことである。

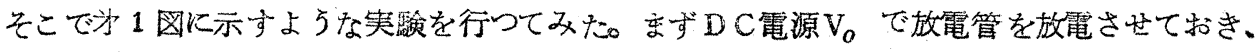
$\mathrm{AB}$ 端子に単位関数形の摂動電圧 $\Delta \mathrm{V}$ を加えると串 2 図に示すような電流が流れる。

円筒形低温プラズマに用いられる所謂 $\mathrm{D} i f f u$ s $i$ on Theory K対し、摂動の計算を行 つて電流波形を求めてみると为 1 近似として

$$
\begin{aligned}
& \Delta i=\Delta \mathrm{V} / \mathrm{R}\left(1-e^{-t / \tau}\right) \\
& 1 / \tau_{0}=k g^{\prime}\left(\mathrm{R} / \mathrm{R}+2 \mathrm{R}_{0}\right)
\end{aligned}
$$

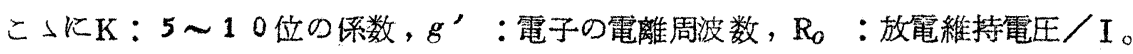
実駚値と計算値の比較の 1 例を示すと、放電管直経 25 mam、封入気体 $\mathrm{A} 、 20 \mathrm{~mm} \mathrm{H}_{\mathrm{g}}$ 、 $\mathrm{I}_{o}=$

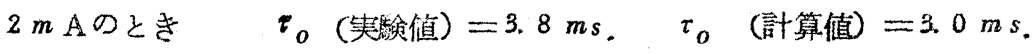

このように相当よい一致か得られこのことから筆者の考方方が妥当であることか分る。又 この奉験は号の測定にも応用できそうである。 


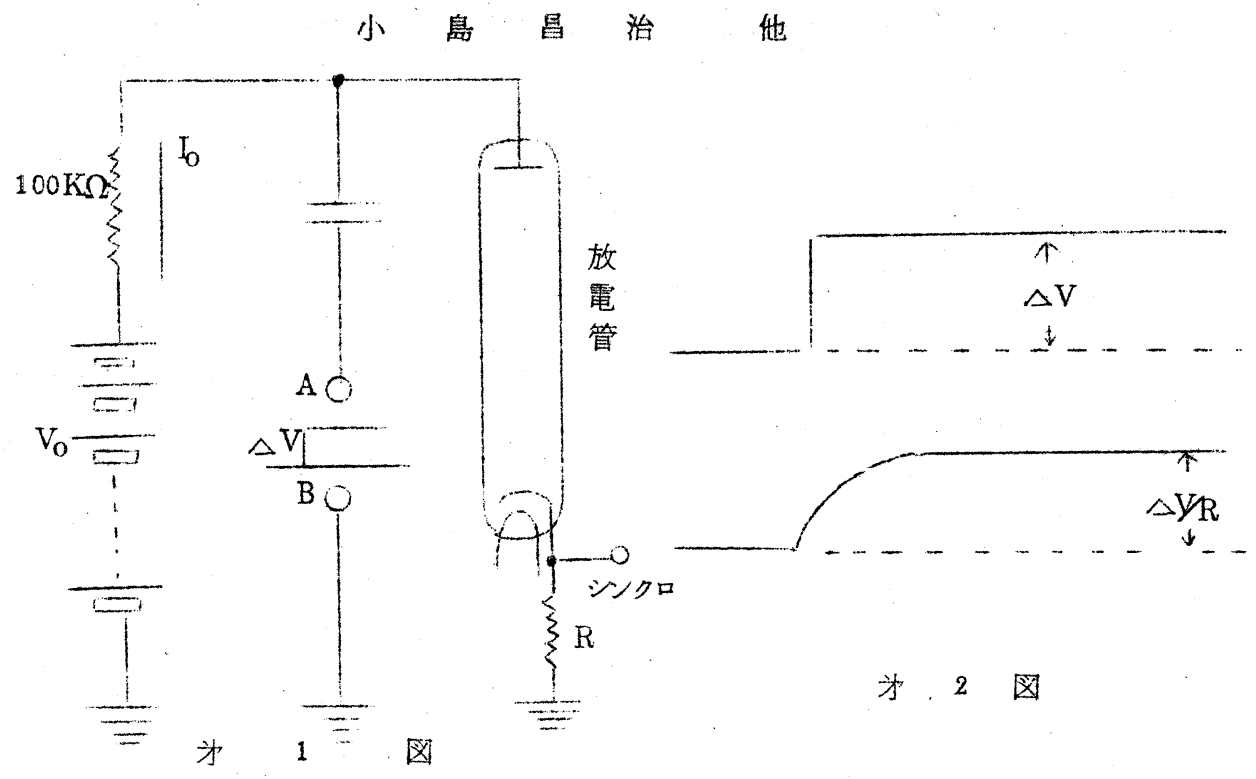

8. 鞘の応答時間

\section{通研土手敏彥}

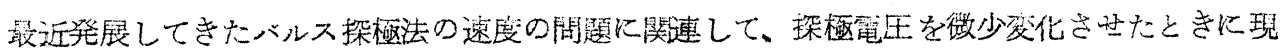

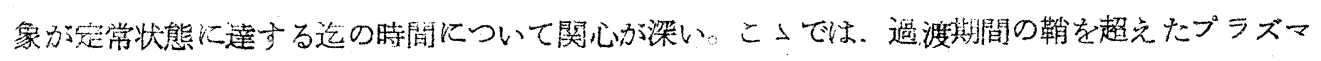

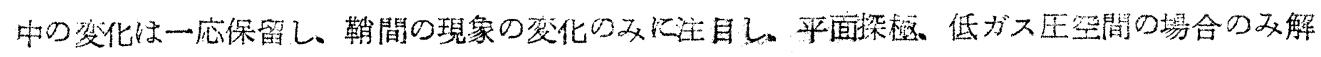
析した。

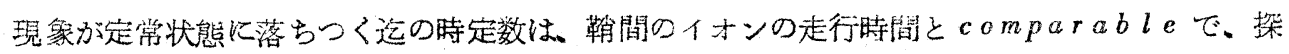

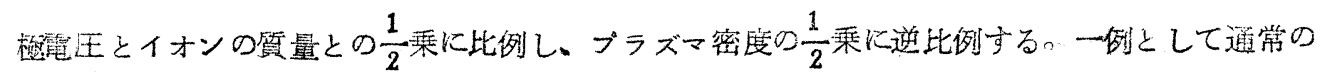

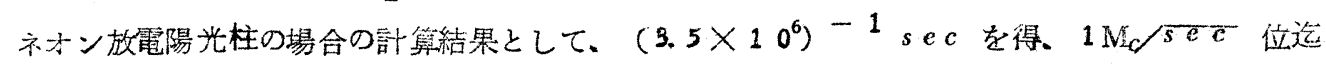
の㳊化には正規に応答することが分つた。

(为 2 回測定研究会追加講演)

\section{9. 電離層の正イオン密度測定法}

$$
\text { 通研 一宮虎雄、高山一男 }
$$

1. 電離層に於いては紫外線によつて平面探針から放射される電子の数は捕集されるイホン数の $10^{3}$ 倍以上になることを推定した。

2.このよらな場所に於㚈るイオン密度の測定に適する球型網状探針を提出した。

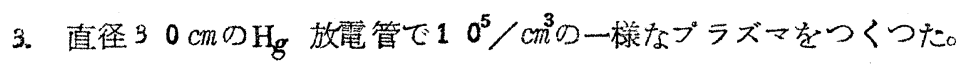

4.この放䉓管でプラズマの密艮が小さいときは球型絧状探針は完全球探針として作用すること 它示した。 
昭和 34 年度ブラズマ测定研究会のまとめ

5.ロッツトに積む装置をつくりこれが探針特性を記録することを示した。

\section{0. 高周波電圧を重畳した探針測定}

通研高山一男。大原省爾、池上英雄

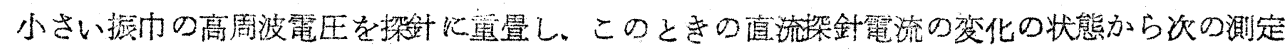
が可能であることを示した。

1. プラズマに低周波旅野が多る場合の探針特性の説明

2. 極低密度プラズマを利用すれば探針とブラズマの麗子の応答

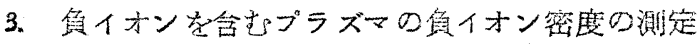

1 1. Glowing Probe 亿よる架間電位の測定

\section{楊北大工 八田吉典。佐藤益美}

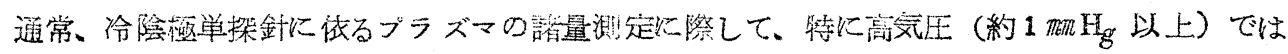

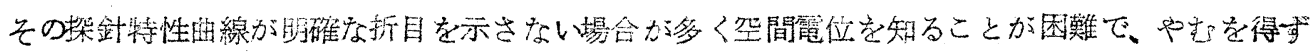

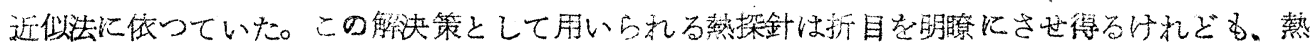

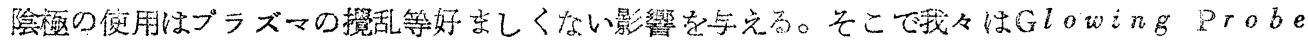
を芳案し、熱探針と同じ效果を得ることが出来た。

このPrabeの構造は次のよ5である。道当な舆当のN の一端を目の細い $N_{i}$ の網（試作例では100メッシュ）で閉じ、円筒側面はガラスを巻いて絶

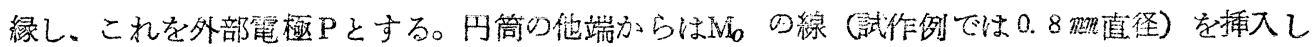
て内部丈は中心䉓極 Cとする。 Pを正極、Cを負極としてPーC間にG $l a w$ 放電を行なるせると $\mathrm{P}$ - C間に生じたプラズマ篦子及イオンはPの網を遥過して外部に放射される。この際イオンの 放射電流は電子のそれに比して無視出来量である。

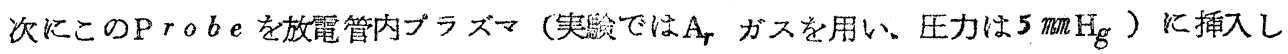

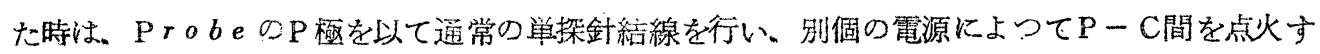

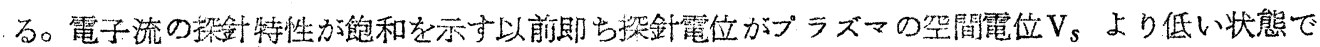
は、Glowing P P r obeからの電子の放出ふ行なるれ、プラズマから探針流入する電子流と

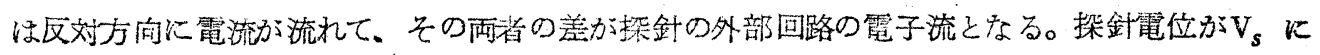


小島昌治他

等しくなつた時。更にVsより高い時はもし電子の初速度の影響を無視すれば、Glowing

$\mathrm{P} r$ ob e からの電子の放出は行なわれず、探針の外部回路には純粋に電子の飽和電流のみが測定 される。従つてここではProbeからGlowing が行なわれているか、いないかには無関系に 同一探針曲線を得る。即ち $\mathrm{G} l o w i n g$ ProbeKグロ一放電をさせない状態 $(\mathrm{P}-\mathrm{C}$ 間点火せ ず）とグロー放電している状態 $(\mathrm{P}-\mathrm{C}$ 間点火) との二つの探針測定を行つて同一紙面にプロッ トす秃ば、その両曲線の分岥点が $V_{s}$ を与える。その測定の1例を下図に示す。

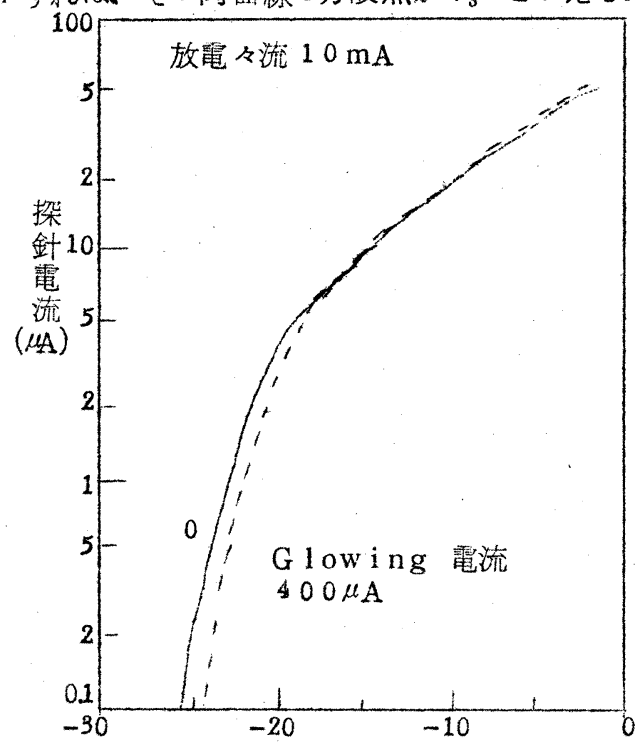

この方法に括いて、熱探針の如くプラズマに 対する熱攪乱のないこと、Glow 点火故に速 みやかな枕答が可能で、バルスによる測定が出 来ること等、プラズマの架間電位決定の新しい 手段になると思わ机る。

探針笔位(V)

(b) 磁気挆針。その他

12. 磁場を横切る拡散の測定

東北大工 八田吉典、管原害。佳藤益美

プラズマを磁場内滥いた場合、電子及びイオンは力線の周りルラーマーの迴転運動を行い、 このために磁場に垂直な方向の電子及びィオンの拡散倸数、移動度は減少する。従つて磁場に垂 直な方向の搪散は全体として抑制される。磁場に詨するこの依存性を調べることによつて、磁場 下にあるプラズマの古典的理論をチェックすることが出来る。

我々は次の方法を採つた。即ち円筒容器の一端にプラズマ源を設ければ。他端にプラズマが達 するまでに管径方向への拡散損失のためにその密庋は隇衰する。管軸方向をZ軸とすれば、磁界 がない場合に任意の軸上の点に和ける笔子密度 $n$ には

$$
N=N o \varepsilon \frac{-\frac{2405}{R} Z}{-226-}
$$


昭和 34 年度プラズマ測定研究会のまとめ

であり、ここでNoは $\mathrm{R} / 2.405$ は直線の勾配を表わす。次に磁場を管軸方向に印加した場合には前式は磁場のある場 合す両極性拡散であるとすると

$$
\mathrm{N}=\mathrm{No} \varepsilon-\frac{2.405}{\mathrm{R}} \sqrt{\frac{\mathrm{D}_{a}^{m}}{\mathrm{D}_{a}}}
$$

となり、ここで $\mathrm{D}_{a}$ は磁界ない場合の両極性拡散係数、 $\mathrm{D}_{a}^{m}$ は磁場のある場合のそれである。 従つて直線の勾配は $\sqrt{\mathrm{D} a^{\prime} / \mathrm{D}_{a}^{m}}$ 倍だけゆるやがなる。更に $\mathrm{D}_{a} / \mathrm{D}_{a}^{m}$ は電子及びイオンに対 する古典的な理論に従えば次の如くなる。

$$
\frac{\mathrm{D}_{a}}{\mathrm{D}_{a}^{m}}=1+\left(\omega_{i} \tau_{i}\right)^{2}+\left\{1+\left(\omega_{e} \tau_{e}\right)^{2}\right\} \frac{\mu_{i}}{\mu_{e}}
$$

ここで $\mu_{e}, \mu_{i}$ は磁場のない場合の電子、イオンの移動度、 $\omega_{e}, \omega_{i}$ はそれぞれのサイクロト ロン周波数、 $\tau_{e}, \tau_{i}$ はそれぞれの衝突の間の平均時間である。

实駼では管軸上の密度分布を探剑によつて測定し、減衰の磁場に対する依存性を求め、上揭 げた理諭式との比較を為すことによつて磁場内に蛒ける電子、イオンの衝突理論の妥当性をチエ ックすることが出来る。又磁場の強い場合でのプラズマの発振による拡散の增加も解明出来るも のと思われる。

現在の状況では実駰の为一段階に着手したばかりで、結論を得るまでに到つていない。

13. $\mathrm{T}_{\mathrm{o}} \mathrm{r}$ o i d a 1 放電の電流電压の測定

電気試験所 藤幸生。竹村直、多田照子

Tor o i d a l 無電極放䉓の基碄的性質である放笔々流及び放電路にか〉る電圧を求めるため K Rogowsky coil 法及び1 tum coil 法について考察し、実験的に検討したので 为一回ブラズマ測定研究会において報告した。

Rogowsky coil による放笔々流の測定法は，Rogowsky cooil を測定しようとす

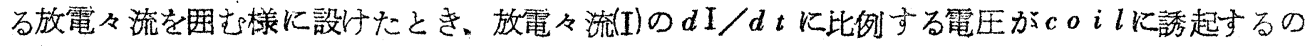

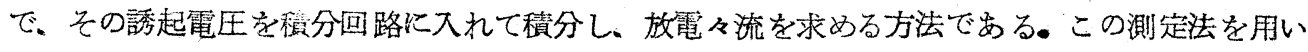

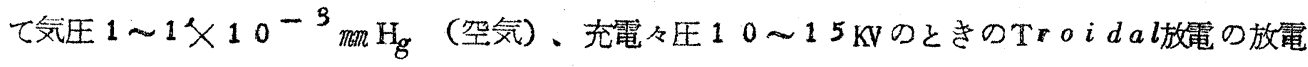
麗流を測定した。測定に当つて最も問題となかのは測定磁界以外の電磁界によつて測定回路に電 殴が誘起し测定結果保誤差を与えることで、この誘導が入るのを防ぐために、遮蔽には特に注意 
しなければならない。

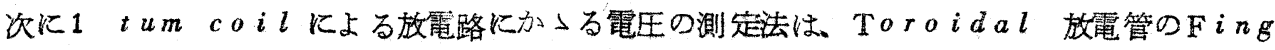
に治つて1巻きのcoil を設け、放電路にか」る電压を測定する方法であるが。放電路にか」 る電圧 $e_{2}$ と 1 tum co $i l$ Kよつて測定される䉓圧 $e_{3}$ との関係が、測定回路の等価回路に よる考察から次の関係にあることを得た。

$$
e_{2}=e_{3} \mathrm{M}_{12} / \mathrm{M}_{13}
$$

$\mathrm{M}_{12}$ : 励磁導体と放電回路との閒の相互インダクタンス

M3 : 励磁導体と 1 tum coil との間の相互インダクタンス

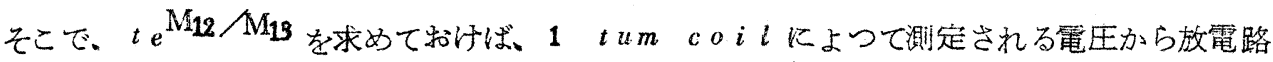
にかかる電压を求めることが出来る。この場合にも測定回路に入る誘導電压が諨差となるから、 その遮蔽には充分注意しなければならない。更に以上の測定法を用いたToroidal 重畳放電 の測定結果をも報告した。

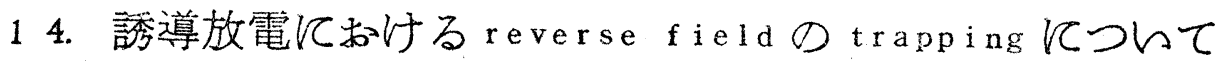

日大理工 内田岱二郎、浜田繁雄、佐藤正知 コンデンサー放電によつてコイル内の気体に誘導放電を和こさせる塨合、誘導放電に、普通、 コンデンサー放電のはじめから和きるとは限らず、密万为 2 半周波以後に生ずることが多い。そ して一旦扣きると、後は半周波毎に同様の誘尊ピンチ現象が繼这されるが、その際、任意の半周 波のはじめ、誘導ピンチがはじまる直前に叔いて、その前の半周波に生じた磁場の一部が、末だ プラズマの中残り、トラップされていることが、コイルと放電管との閒に入れたmagnetic pvobeによつて得られたデータから推論された。

この磁場のTrapping という現象は明らかにブラズマの有限な電気伝導度によるわけであ るが、磁場の拡散のメカニズムとしては、プラズマの半径方向の運動を考慮する場合と、しない 埸合とが考えられ、それらのモデルを実験にあてはめてみると、気体に1 $0^{-2} \mathrm{~mm} H \mathrm{H}$ 程度の空 気を用いたときは、プラズマの運動を考虑に入れるモデルの方が、今の姏、実験とあうようであ る。

前の半周波に生じた磁場は、次の半周波に生ずる磁場と问きが逆なので、ピンチが始をつた直 後では、プラズマは、内と外とで互いに逆むきの磁場にはさまれた。中登のプラズマになつてい る多のと想像される。 
昭和 34 年度プラズマ測定研究会のまとめ

誘導ピンチに呫ける、このreverse trapping fild 味めることであり、その後、放電管内中央磁場の時間的变化を、管内に入れた $m a g n e t i c$

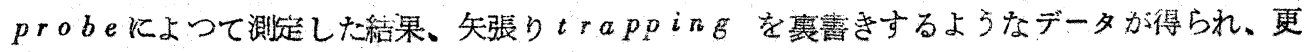
に1 $0^{-1}$ mm $\mathrm{H}_{g}$ のアルゴンを用いた場合は、生じたプラズ、が㫢間的にきれることなく、連続 して存在していると考えられている。

\section{5. 電気試験所に於けるシラ一型放篭の研究}

電気試験所川俣修一郎、木谷芳二, 横田茂。小川潔 杉浦蜸、井口正之。相原秀行、高木勝正

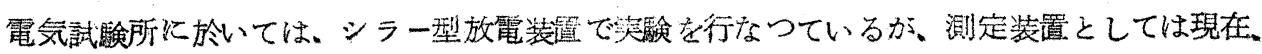
分光器、磁気探針、高速流しカメラ及びシャントロゴースキコイルによる電流測定を行なつて いる。分光器堅俰については、他に報告したの答ここでは高速カメラ及び探針ロゴースキ。ュイ ル炕よる測定結果を述べる。

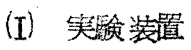

実験回路及び放電管は为 1 圀に示す通りで 放笔管材料はモリブデンガラスでめる。

（）测定装置

（片高速流しカメラ 最高流し速度は $4500 \mathrm{~m} / \mathrm{sec}$ て で、フルム任固定し、外部加 らスリットを通して入射した光は８角ミラーで 回転し、フイルム上に像を結ばせるすので㐫る

(11) 磁父探針 半径 $1 \mathrm{~cm}$ 硬質ガラスの管 の中に 10 ターンのコイルを挿入し、プラズマ 電流及び一次電流による放電管内磁束変化を測 定する。
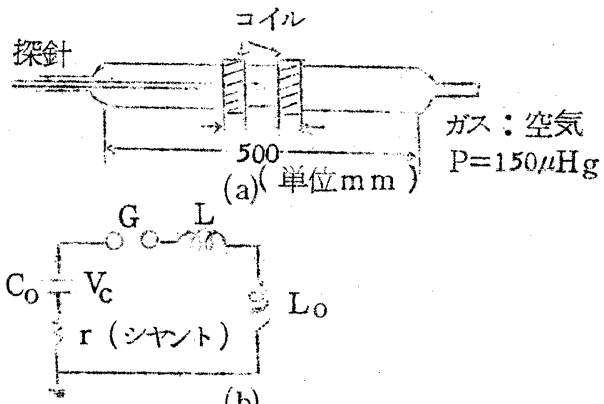

(b)

$\mathrm{C}_{0}: 8 \mu \mathrm{F}$

$\mathrm{L}_{O}:$ : イルL $\quad 0.6 \mu \mathrm{H}$

$\mathrm{L}:$ 外部の $\mathrm{L} \quad 1.0 \mu \mathrm{H}$

$\mathrm{V}_{\mathrm{C}}: 50 \mathrm{KV}$

放電及流 (一次) $100 \mathrm{KA}$

放電周波数 $45 \mathrm{KC}$

为 1 図 放篦管及放電回路

(iil) ロコ゚ースキーコイル

(V) シャント。電圧計

( ) 測定結果

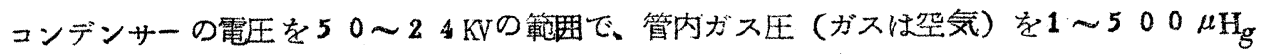

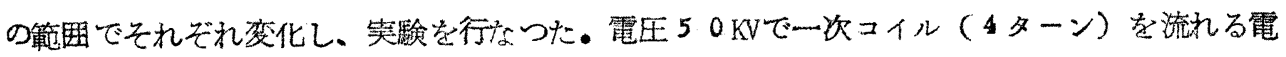


小島昌治他

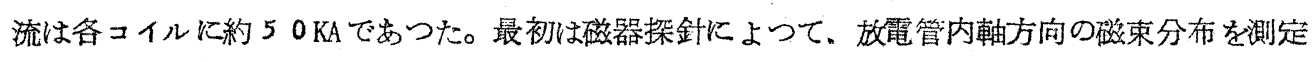
し、三次測のガス放電を行つた時と行なわない時の磁束分布を比較し、放電を行なつた時は磁束

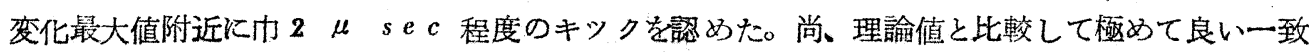
をみた。 尚測定は差働增巾器付きのシンクロ・スコープを用い、誘導等による障害は全くみら れなかつた。その他、ロゴースキーュイルを試作して、一次側の導体を貫通させ、シャントによ る測定結果と比較検討した。 こ ${ }^{(3)}$ この場合、積分器等に相当の誘導を受け可成りの誤差を生じた。 次に高速流しカメラが運転できる様になり．プラズマの軸方向の運動及ぴ半径方向のプラズマ 圧縮速度を測定した。 の压縮は为 2 図の栚汸放電管の一

端を切り落とした構造のものを用い Wた。

カメラによつて、各時刻に於忷 るプラズマの形と、位置が判つた ので、各時刻に於忛る、プラズマ と磁気探針の相互インダクタンス か計算できる。又先に述べた様に

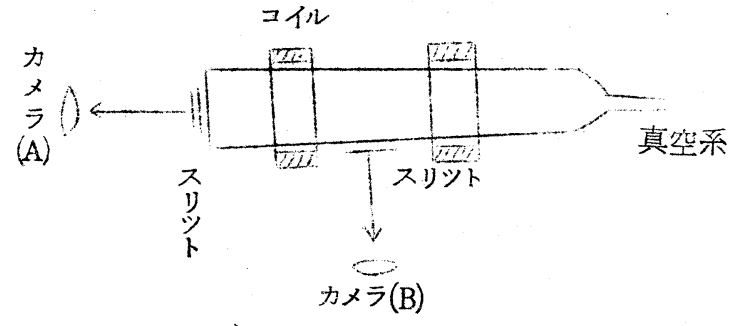

为2図 カメラの位置
(A) 半径方向圧縮速度の測定
(B) 軸方向運動速度の測定

磁束の最大值附近に入るキックは 二次ブラズマ電流によつて生ずる 磁束変化と考㝋られるから、次の 関䋆式からプラズマ電流を求める 事がでる。

$e=\frac{d \Phi}{d t}=\frac{d\left(\mathrm{MI}_{2}\right)}{d t}$

$=\mathrm{M} \frac{d \mathrm{I}_{2}}{d t}+\mathrm{I}_{2} \frac{d \mathrm{M}}{d t}$

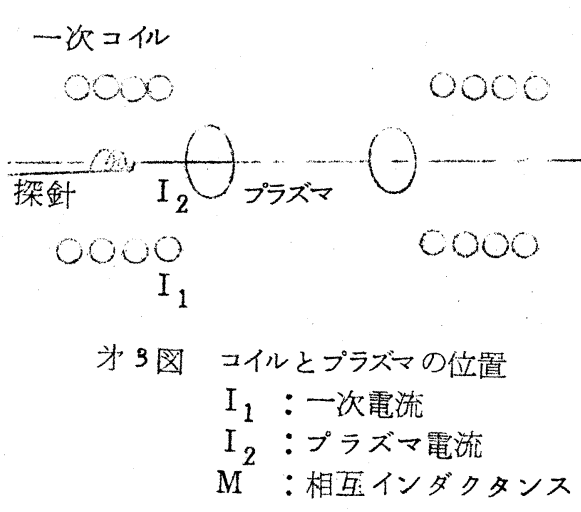

ここにeは二次電流によつて生ずる磁束変化で、探針に謡起される䉓压であり、I 電流、Mは为 3 図に示す 2 個のプラズマと探針コイルの相互インダクタンスである。この微分方 程式をアナ。コン等によつて解けば、 $I_{2}(大)$ が求められる。数值計算を行なつた結果によると

※，電試竹村直より脚報告あり 
昭和 34 年度ブラズマ測定研究会のまとめ

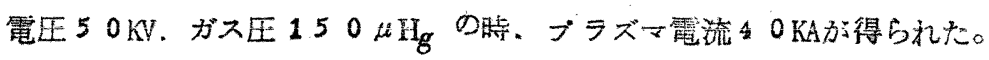

この䜌果を実験的に絤討したいと考光、为 4 図 の椂な放電管を作り、点線の位置にロゴースキー コイルを拽入して夷駼を行なつだ(6) その結果. $20 \mathrm{KA}$ と云う結果が得られ、上の計算結果と比整 し、プラズマ電流のオーダーを知る事ができた。

（）昭和 34 年の 3 回の測定研究会に発表した

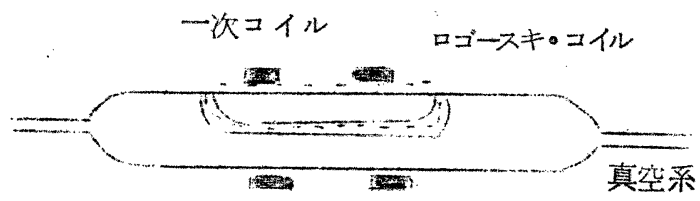

为4図ロゴースキ。コイル 内容は大体この程度のものであるが、現在の所更 に進んで、ブラズマの放電の機構、加熱の問題、運動の解析を行なう予定である。

（）発表論交及び研究会、（発表者は○印を附す）

(1) 磁気探針によるシラ一型放笔管内の磁測分布の測定 川俣修一郎 小川 潔 ○杉浦 賢 相原秀行 (矛 1 回研究会)

(2) 瞬間写真 伏見光造 O井口正之（为 1 回）

（3）ロゴースキ。コイル ○谷芳一 横田 茂 高木勝正(为 1 回)

（4) 高速流しカメラKよる研究 ○井口正之 相原秀行（为 2 回）

(5) シラー型放電二次電流の計算 川俣修一郎 小川 潔 ○澎賢 井口正之 相原秀行 (为 2 回)

(6) シラー型放電管内の電流測定（ロゴースキ。ュイル）川俣修一郎 小川 潔 杉浦 賢 井口正之 ○相原秀行 (为 3 回)

16. 試作放電間隚について

電気試験所 竹村 直、藤 幸生。多田照子

蓄電器の放電によつて、低気圧中に衝熬大電流放電を起させ、超高温プラズマを発生させる装 置に捛いては、放䉓用スイッチを必要とし、この機構が重要な問題となる。

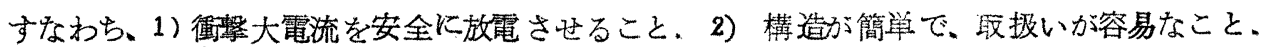
且つ電柱の消耗が少ないこと、3）スイッチ自笨のインダクタンスが小さいこと、4）放電時、

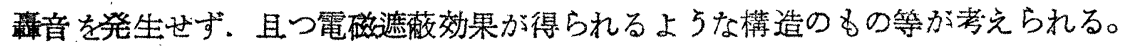

よつて、当所に於ては、これらの諸点をかなり满足することの出来る構造の放電間隙を設棓十 試作したので、この結果について、为3回ブラズマ測定研究会に於て報告した。 


$$
\text { 小島昌治他 }
$$

すなわち、この放電間戃の構造は、数個の電柱を有する多重間除から成立つて沏り。これらの

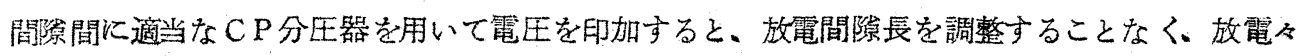
王、5〜30 KVを容易に且つ確実に得る事の出来るようにしたるのである。

又、この多重間吵を銅筒及び鉄筒に入れる事により、遮音、電磁遮蔽を行い得るよ5にし、且 つ、帰路の電流を銅筒に流す事により、インダクタンスをなるべく小さくするようにしてある。 これらの諸特性の詳細な实験及び他の構造のスイッチ、例えば真空、イグナイトロンスイツチ 等の比較は今后の研究䛲題である。 
II. 光 学

(a) 分光測定

1. 阪大理学部になお计るプラズマの分光学的熕定およひメ線測定

阪大理学部

沢田昌雄、白石俊男、石村勉、 塯江忠男、名倉卓行、大塚正元

1. 水流、アルゴンガス、窒素ガス流で安定化した三種のプラズマジェット発生装置が設計試作 された。電気特性はプラズマピンチの種々の条件の下に測定された。プラズマジメット、およ び、両極間にいわゆるサーマルピソチでしぼられたプラズマ柱の盜度が分光学的に測定された。 水で安定化したプラズマジェットの温度はH马 線のシュタルクプロードニングと、 $\mathrm{OH}(0,0)$ バンドスペクトル中の回転線の強度分布により測定した。アルゴンプラズマ柱の温度はスペク トル線の位置的強度分布より測定した。このさい、イオンの密度を知る必要があるが、 $\mathrm{S} \mathrm{aha}$ 式よりもコロナの電離式の方が適当である事が解つだ。また、理論と実験との差から、電離、 励起にあつかかる $\mathrm{kT}$ に比較して高エネルギ一電子は、Maxwe 11 分布からかなりずれている のではないかとの疑問が指摘されたが、詳細は検討中である。

2. 大電流值線放電。シラ一型放電を観測するため

(1) プラズマからの輻射を分光した後に高速度流しカメラで最影する"分光流しカメラ"が計 画されている。これは明るい分光器を必要とするが、プラズマの状態を元素、電離度の異な るイオン等に分け、且つ同時に観測するのを目的とする。

(9) 真空紫外領域でスペクトル線の強度を光笔子增倍管で榆出する "真空紫外分光光度計 "が 島津製作所で製作中である。

軟X線領域の制動輻射測定の為、"平面回折格子分光器" "結晶分光器 "が製作中である。

\section{2. 電気試験所にお计るプラズマの分光学的測定の概娶}

電気試験所

藤 幸生、竹村 直、鳥越 泰

当所に於いては、高温プラズマの状況を観測するため、昭和 33 年度に島津製エバート型平面 
小島昌治他

回折格子分光写真器を購入し、豫備実験としてシラ型放電管を用いて実験を行つた際、スペクト ル写真を撮影したので、これについて簡単に为一回プラズマ測定研究会に報告した。

使用分光器の性能：線引面積 $56 \times 128 \mathrm{~mm}$, 分散逆数 1 次 $2.5 \AA$ 解, $(1200$ 本 $/$

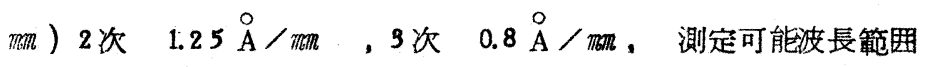
$2500 \AA \sim 7500 \AA$ (一次)

実験装置及び条件： 実験に使用した放電管は、直径 $6 \mathrm{~cm}$ モリ゙デン硝子製直円筒型のるので、 シラ型放電を行わせた。

スペクトル撮影時の印加電左は、35〜40 kV 、管内圧、 $2 \times 10^{-2} \mathrm{~mm} \mathrm{Hg}$ 、放電々流 $20 \mathrm{kA}$ で、撮影は放電を50回繰返して行つた。

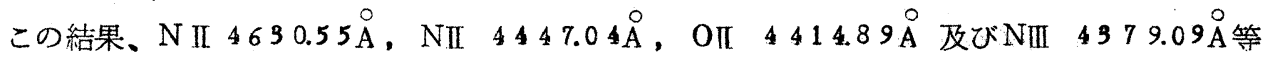
が認められたので、この時のプラズマの温度は数 10 万度程度であると推定される。

なお、今后の問題としては、感光特性の極く秀れた感光材料、ブラズマ像又はスペクトルの瞬 間撮影に充分適用し得る感度と波長範团を有する乾板又はフイルムの開発、及び測光法に関する 研究を行うことが目下の急務と考えられる。

3. プラズマの温度と電子密度の測定

東大航研

村川永、橋本静代

およそ5 m $\mathrm{Hg}$ の気任のネオンをつめだカイスラー管に火花放電を通らせて、これから出てく る光のスペクトルのうちNeId5852のプロフイルをFabry-Perotのエタロンで測定、ま たその波長とアーク放電から出てくるNeI $\lambda 5852$ の波長とくらべて、前者は $\Delta \nu_{\mathrm{dis}}=0.027 \mathrm{~cm}^{-1}$ だけ赤の方へずれていることを見出した。火花放電によつて得られる NeI $\lambda 4715$ 及び H ロフイルから電子密度 $\mathrm{N}=4.8 \times 10^{15} / \mathrm{cm}^{3}$ を得た。イオンと電子とが中性ネオン原子に扣よぼす 影響（ドップラー効果を無視して）だけでNeIス5852のプロフイルの半值巾が $\Delta \nu_{\mathrm{h}}$ となると すれば、Lindho $\operatorname{lm}$ によれば

$$
\begin{aligned}
& \Delta \nu_{\mathrm{h}}=\mathrm{A} r^{2 / 3} v^{1 / 3} \mathrm{~N} / \mathrm{C}, \\
& \Delta \nu_{\mathrm{dis}}=\mathrm{B} r^{2 / 3} v^{1 / 3} \mathrm{~N} / \mathrm{C}
\end{aligned}
$$

と畵くことができる。但しケは二次シュタルク効果の定数とする。 
昭和 34 年度プラズマ测定研究会のまとめ

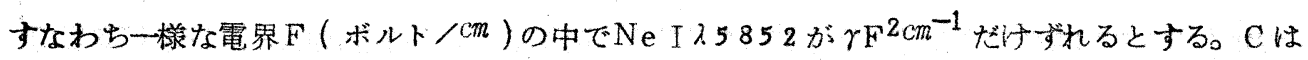
光の速度、vは電子の平均的速度である。Lindholmは理論的に $\mathrm{A}=0.0450, \mathrm{~B}=0.0387$ を 得た。実験的には $B=0.018$ とする方がよいということがかかつた。LindholmのAの值は 実験的にしらべることがでさないので、これを正しいと仮定すると、 $\Delta ע_{\mathrm{h}}=0.067 \mathrm{~cm}^{-1}$ を得る。 これを観測したNe I $\lambda$ 5 852 のプロフイルの半值巾から（ベクトル的に）差し引けばドップラ 一効果だけによる半值巾 $\Delta \nu_{\mathrm{D}}=0.192 \mathrm{~cm}^{-1}$ が得られる。これからプラズマの平均的温度として $\mathrm{T}=4.9 \times 10^{3} \mathrm{~K}$ を得る。

次に気圧が $1 \mathrm{~mm} \mathrm{Hg}$ よりる小さいと思われるへリウムのガイスラ一管に火化放電を行なつて

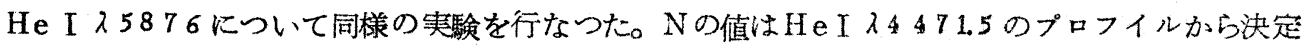
した。今迄得た実験的データでは Lindholm 式はA $=0.0450, \mathrm{~B}=0.018$ と拈けば少 くとも定性的には正しいといらことがわかつた。これに関するもつと詳しい実験を目下続行中で ある。

4. 水素プラズマの分光学的温度測定

日近中研

山本学

日本物理学会欧字報告 14 巻（1959）1739頁に発表のため略す。

5. 日大におけろプラズマの光学的研突

日大理工学部物理教室 横田昌厸、吉村久光、大西晴幸 川崎栄一

日大に建設中のmir r or 型装置での誘導電場による放電の成長を調べるため 20 ターン、 $19 \mu \mathrm{H}$ のコイル、内経 $13 \mathrm{~cm}$ の石英放電管を用い、コンデンサー $(4 \mu \mathrm{F}, 30 \mathrm{kV})$ 放電を行い。 その際の発光をphotomultiplier 6364 及び水晶分光器QL-170 で測定を行つだ。

i ) Photomultiplier による測定

空気、窒素、水素、アルゴンの各ガスについて各々10〜 $100 \mu \mathrm{Hg}$ 程度の気圧の所でのオ ツシロの pulse波形を撮影した。この際各種のフィルターを入れることにより、空気、窒素 アルゴンでは原子 $\rightarrow$ 分子、 $A_{\mathrm{r}} \mathrm{I} \rightarrow \mathrm{A}_{\mathrm{r}} \mathrm{II}\left(\mathrm{A}_{\mathrm{r}} \mathrm{III}\right)$ )発光機構の移り变りが観測された、又放電管 
小島昌治他

の軸上のことなる場所からの光を各々異るスリットから取出して得た puls e 波形は放電の 軸方向への伝播の特徴を示している。

ii）分光器による測定

波長範网 $3200 \AA$ 〜 $8000 \AA$ で測定が行われた。露光時間は $\frac{1}{1000}$ 秒から $\frac{1}{100}$ 秒の間で、 強力增感現像を行つた。Fuji のNeopan SSS 及びKodakの航空用Superpan XX を使用した。このため粒子があれて線巾の測定は誤差がふえた。空気、窒素に関してはNI、 NII、OII、アルゴンではA rIII まであらわれた。密度は $10^{16} / \mathrm{cc}$ でイオン温度は 20 万度前 後と推定された。水素以外の放電では不純物として水素、水素の放電ではNが混入した。今後 線巾のげんみつな測定、電子温度、及びその時間的変化の測定を行う。

6. 高温プラズマのスペクトル

名大工応物 吉 原 邦夫

電気工学教窐の超高温プラズマ装置の温度測定を目的としてスペクトルの撮影・測定を行つた。 装置は中型水晶分光器 (島津 $Q F-60$ 相当 分散 $10 \AA / m$, 2.2700 )、及び小型可視部分

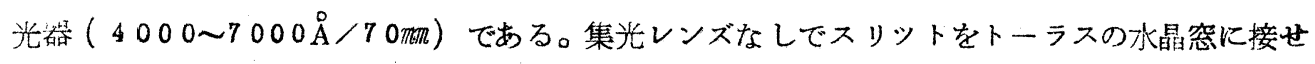
しめて撮影した。

主放電の前に放電を容易ならしめるため、予䚚放電を行うが、この放電のスペクトルが主放電 のそれに重なる恐れがあるので、之を確かめるため予備放電を、実際の場合と同程度の時間、露 出撮影した。その結果予備放電のスペクトル強度は無視できる事を知つた。

主放電の撮影は 放電電圧等にすよるが、約二百回以上の放電が必要であつた。通常、一回の 放電に 15 秒以上を要するので、露出は 2 時間程度を要する。

主放電スペクトルに、OV2781は現れていない。之はまだ温度の低い事を意味する。HeI， H eII のスペクトル線は分散のよい波長領域に現れなかつたので、巾の測定はできなかつた。

主なスペクトル線としてはB a l m e r 系列が強く、HeI のスペクトル線もかなり著しい。 HeII は4686̊と思はれる線があるが、この系列の他の線が見当らないので不確実である。何

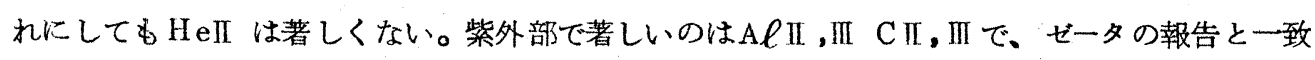
する線が多い。以上のすべてをまとめて著しいスペクトル線の励起電肚を調べると $10 〜 50 \mathrm{eV}$ 位になる。A 
昭和 34 年度ブラズマ測定研究会のまとめ

示す。

現在までのデータでは温度の推定はできないが、プラズマが或程度熱平衡に近いとすれば次の よ5に考えられる。バルマー線の強いのは数萬度であるが、ブラズマの温度の上年する途中に発 せられるとすれば最高温度はもつと高いであろう。しかしHeII の線の弱いことから50 万度以 上とは考えられない。

(b) カメラ、その他

7. 高速度撮影によるプラズマピンチの観測

阪 大. I

山中千代题、和田弘名、山村 豊

筆者らは高温プラズマ研究の一手段として回転鏡流しカメラ、ケルセルカメラ、フアラデーセ ルカメラを製作し低気圧中の大電流直線放電及びアルゴン中の衝撃波の特性を観測した。電気的 特性としては同軸シャント、ロゴフスキーコイル、同軸相互インダクターを用、電圧、電流、電 流変化率を同時に測定した。

直線形放電としては直径 $65 \mathrm{~mm}$ 長さ300 m のガラス管中で $10^{-2} \mathrm{~mm} \mathrm{mg}$ 空気の放電を行なつた。 充電容量 $7.5 \mathrm{KJ}$, 電流最大值 $7 \times 10^{4} \mathrm{~A}$, 予備放電は $150 \mathrm{~W}, 30 \mathrm{MC}$ で実施した。ピンチの 模様は流しカメラ、駒取りカメラで捕え、不安定性の観測と共にピンチ速度 $6 \times 10^{4} \mathrm{~m} / \mathrm{sec}$ を 得ている。

衝撃波管としては直径 $38 \mathrm{~mm}$ 長さ $1000 \mathrm{~mm}$ のガラス管中に $3 \mathrm{~mm} \mathrm{Hg}$ のA 封入し、シラ形 の放電で衝撃波を発生させ軸方向の伝播速度を高速度撮影で求めた。衝撃波はコイル電流の ring ing に応じて数回発生し为 $2 \mathrm{shock}$ が最も高速で $2000 \mathrm{~m} / \mathrm{s}$ 程度であつた。

8. 気体衝撃波の $\mathbf{X}$ 線瞬間撮影

東大理滳房夫

荷電されたコンデンサーを細い針金で短絡する時に生ずる電気的爆発は、X線による瞬間写真 で、その時の金属蒸気の発生、拡散等の状況を非常に明瞭に観察出来るが、それと同時に発生し ている架気の衝撃波は、針金の軸方向にX線影写真をとる事によつてはつきりと観測できる事が 
小帠昌治他

亦された。その時の針金は $0.33 \phi \pi$ 既 のフユ一ズ線、コンデンサーの荷電は $1 \mu \mathrm{F} \times 10 \mathrm{kV}$, X線管の陽極電圧は $36 \mathrm{kV}$ である。(物理学会誌 14 和3('59))

又、同じ椧陰極型のX線管を用いて、衝撃波管内の衝撃波を非常に軟かいX線を用いて瞬間撮 影绌来る事が示された。( J. Phys. Soc. Jap.14 ('59) 664, F. Tamaki, and C. S. Kim)

現在までに、気体の密度差をX線により瞬間摄影したものとして、上記の外に、メチルアイオ ダイドを混せた空気の衝撃波の撮影。( G. Schall u. G. Thomer('51)) 又, $\mathrm{CO}_{2}, \mathrm{Argon}$. 冞気中のs parkの写真 (K. H. Herrmann ('58))がある。

以上の研究で、無機のガスの場合でも、写真のコントラストをつける為に特に何も混ぜなくて

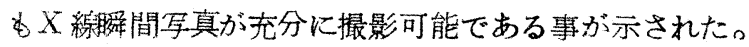

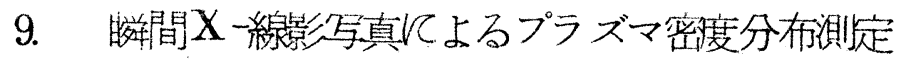

東大・理平田森三

高真空中における椧グリツド電極火花放電の誘発により、継続時間 $1 \mu \sec$ 程度のX一線を発 生させ、これによつて金属線の電気爆発による金属蒸気の飛散状態、それに伴 5 空気中の衝撃波 ${ }^{1}$ 或は低圧ショック、チューブ中の障慧物による衝慗波 ${ }^{2)}$ などの瞬間X一線影写真を撮ることがで きる。

この方法を利用して、低圧放電管の中で放笔中の気体密度分布を測定することが可能か否かを 梚討した。

強度 $\mathrm{I}_{0}$ の入射 $\mathrm{X}$ 一線が放電しない状態の放電管中の気体を通過して写真乾板に達するときの 㤝度をI、放電中に管中に生じた密度增大部（厚さ $x$ ）を通過して乾板に達する強度を $\mathrm{I}^{\prime}$ とす る。気体のX一線に対する total mass absorption coeffieientを年, 気体 密度を $\boldsymbol{\rho}$ 、放電中密度が增した部分についての両者をそれぞれ $\mu_{\mathrm{m}}^{\prime} ， \rho^{\prime}$ とし、且つ

$$
\mu_{\mathrm{m}}^{\prime} \rho^{\prime} x=(1+\mathrm{n})^{\mu}{ }_{\mathrm{m}} \rho x \text { と表わしたとき。 }
$$

$\mathrm{n} \mu_{\mathrm{m}} \rho x \ll 1$ とすれば

$$
\mathrm{I}-\mathrm{I}^{\prime} \div \mathrm{I}_{0} \mathrm{e}^{-\left(\mu_{\mathrm{m}_{0}} \rho_{0} x_{0}+\mu_{\mathrm{m}} \rho x\right)} \cdot \mathrm{n} \mu_{\mathrm{m}} \rho x .
$$

但し、 $\mu_{\mathrm{m}_{0}} \rho_{0} x_{0}$ はX一線管と放電管の隔壁のセロフフン及び乾板の前におく遮光用黒色セロ ファン等による吸収効果に対応する量とする。

乾板の黑化濃度が $X$ 一線強度に比例するような適正現像を行つたとき。（IーI'）に対応す 
昭和 34 年度プラズマ測定研究会の妾とめ

する濃度差（ $\mathrm{B}-\mathrm{B}^{\prime} ）$ が検出可能の大きさを持つためには、まず、 $\mathrm{I}_{0}$ を大に、 $\mu_{0} \mathrm{~m}_{0} x_{0}$ を 小にすることが必要であるが、今までの実験の結果によれば、七ロファン膜( $\left.\mu_{\mathrm{m}_{0}} \doteqdot 400, \rho_{\mathrm{m}_{0}} \doteqdot 2\right)$ ) 厚さ2 $\mu$ で、乾板を充分に黑化させる $\mathrm{I}_{0}$ が得られる。そこで、密

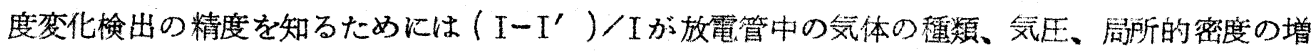
加率 $\mathrm{n}$ にっていかに変るかを験べるのが便利である。

$$
\left(\mathrm{I}-\mathrm{I}^{\prime}\right) / \mathrm{I} \doteqdot \mathrm{n} \mu_{\mathrm{m}} \rho_{\mathrm{m}} x \text {. }
$$

気体としては空気及び水素を例にとり、X一線の波悵 $6 \AA$ 月, $10 \AA$ の場合の $\mu_{\mathrm{m}}$ の值を求め ${ }^{3)}$, 管 内の気压 $10^{-2} m \mathrm{mHg}, 10^{-3} \mathrm{~mm} \mathrm{Hg}$ のときの $\left(\mathrm{I}-\mathrm{I}^{\prime}\right) / \mathrm{I} ・ \mathrm{n}$ の計算值を次表に示す（但し $x=1 \mathrm{~cm}$ )

\begin{tabular}{|c|c|c|c|c|}
\hline$I-I^{\prime}, 1$ & 空 & 気 & 水 & 素 \\
\hline $\begin{array}{c}X \text { 一線の } \\
\text { 波長 }\end{array}$ & $10^{-2}{ }_{m a m} \mathrm{Hg}$ & $10^{-3} m \mathrm{Hg}$ & $10^{-2} \mathrm{~m} / \mathrm{Hg}$ & $10^{-9} \operatorname{men} \mathrm{Hg}$ \\
\hline $6 \AA$ & $8.5 \times 10^{-6}$ & $8.5 \times 10^{-7}$ & $3.3 \times 10^{-9}$ & $3.3 \times 10^{-10}$ \\
\hline $10 \AA$ & $3.4 \times 10^{-5}$ & $3.4 \times 10^{-6}$ & $1.7 \times 10^{-8}$ & $1.7 \times 10^{-9}$ \\
\hline
\end{tabular}

$\mathrm{n} か ゙ 10^{2}$ 程度の場合を考えても、水素については密度変化をこの方法で検出することは殆ど不 可能である。しかし、空気或は $\mathrm{Ne}$ 等の気体については可能性が考えられる。

1）滳房夫同日のこれに次ぐ講演

2) F. Tamaki and Kim, Chul-Soo, Proc. Phys. Soc. Japan, 14 (1959), 664

3) J. A. Victoreen, J. A. P. 20 (1949), 1141

10. Shock Iuber打万Pulse探鍂による 電子温度とStreak Recordによるイオン温度

阪大工

山中干代龦、和田弘名、山村 豊

筆者らは先に報告したのと同様の $\mathrm{A}$ 封入直径 $38 \mathrm{~mm}$ ，長さ1000 m のガラス製衝撃波管を用 い高速度骤影法とパルス探針法を併用し過渡プラズマの荚験を行つている。電磁コイル駆動によ る衝撃波管は動作が簡単であるから測定法を研究するにも便利である。

Shock Frontに固定した座標系で連続条件と運動亚及びェネルギ一保存則を用いFront 
小島昌治他

での断然圧縮を考虑すると s h o ck 速度の流しカメラ観測よりイオン温度を求めることが出来る。

一方電子温度は J ons on Ma 1 t e r 流に求めることは簡単であるから両者間の消息を調べるこ とが可能である。

電子温度は最大 $25000^{\circ} \mathrm{K}$ で $2 \mathrm{~m} \mathrm{sec}$ 程度の時定数で減衰することが分つた。イオン温度はイ オン化エネルギーの取り方で大いに異なるのであるが 1 価のイオン化のみとすると数 $100.000^{\circ} \mathrm{K}$ に達する。両者の緩和距離は電子の平均自由行程の $\sqrt{\mathrm{M} / \mathrm{m}}$ 程度 $(\mathrm{M}:$ イオン $\mathrm{mass}, \mathrm{m}$ : 電子 mass）と考えられるが略実測と合致している。時間的、空間的にこれらの緩和現象を詳し く調べるのは今後の課題である。 
昭和 9.4 年度プラズマ測定研究会のまとめ

III. マイクロ波

(a) 反 射 法

1. 分布を考慮したプラズマの密度測定

通 研

高山一男、大原省爾、池上英雄

マイクロ波反射法によつてプラズマの密度測定を行 万際、密度分布の非一槏性がどのような条 件下において無視でき。または十分考虑され衫ばならないかが論議された。

プラズマとしての陽光柱は、 $\mathrm{TE} \mathrm{E}_{10}$ モードの電界と平行に4000 MC／S の導波管を串刺しに している。密度分布は半径 $\rho$ の陽光柱の軸に対称、次式で表わされるものと侾えられた。

$$
N(r)=N_{0}\left(1-\frac{r^{2}}{\rho^{2}}\right)
$$

このような密度分布をもつプラズマ中での波動方程式を解き、プラズマ表面 $\mathrm{r}=\rho$ に括いて外部 電瓶界との連続性を用し反射波が定められる。

nをプラズマに対する笔磁波の屈折率とし、 $\mathrm{k}$ を波数とするとき、 $\mathrm{n}^{2} \mathrm{k} \rho \ll 8$ では测定され た反射係数は一様な密度分布によるものと見做し 5 る。 $\mathrm{n}^{2} \mathrm{k}, \rho$ 己 8 の条件では密变の非一様性 を十分に教慮しなければならないことが示される。

以上の理諭的裏付けに従つて、探針法による密度測定結果之の比較を行つたが、探針測定が生 ずる誤差のため十分な測定值の一致をみせることができなからた。

尚、本実験においては、4000 MC/S 波を执ると、1 $0^{13}$ ions/c.c. 程度をでのプラズ マ密度が測定されらることが、理諭的・実験的に立証された。

2. マイクロ波の反射による測定

東京教育大学

小島昌治、加藤清江、萩原茂男

マイク口波の定在波比を測定することによりプラズマの規格化インピーダンスを求める事が出 来てプラズマの規格化アドミッタンスがわかる。この徝は誘電率の1/2乗に等しいからこれを電子 密度の函数としてスミス図表にあらわすと、衝害周波数レとその密度に於けるプラズマ振動の角 周波数 $\omega_{\mathrm{p}}$ との比、 $\nu / \omega_{\mathrm{p}}(=\beta)$ の各值に対して困の様になる。こっで $\omega_{\mathrm{p}}$ ボマイクロウエーブ 


$$
\text { 小島昌治他 }
$$

の角周波数 $\omega$ と一致する点は $\mathrm{P}_{1}, \mathrm{P}_{2}, \mathrm{P}_{3}$ である。一方アドミッタンスを実数部と虚数部とに分 けるか、夺は反射係数と位相のずれとに分けてみると、 $\omega_{\mathrm{p}} / \omega=1$ に相当する点がなお見易くな る。

ブラズマが定常的な場合は上の計算が容易に出来て、 $\beta$ が大きくない限り、ブラズマの電子密 度が求めらたる。しかし過渡的な場合は、各電子密度に対ナる反射率は瞬間的に求めなければな らないので、どうしても定在波測定器の榆波出力をオッシロスコープに入れて、その写真解析に よらねばならなくなる。現在のところ定在波測定器のブローブを一定の間隔で夫々の写真をとり、 各電流に対応する出力をよみとつて佂在波比を求めて一広妥当な結果が得られている。たよ゙マイ クロ波検波器の整合に可成りの問頯 が存在する。

以上の実験は主として10GCのマ イクロウエーブによつて行つた。放 電管は 15 Wの螢光登と、1 $1 \mathrm{~mm} \mathrm{Hg}$ のA をつめた熱陰極放電管で、前者 を過渡的現象をしらべるのに使用し、 後者は定常状態の測定に用いた。

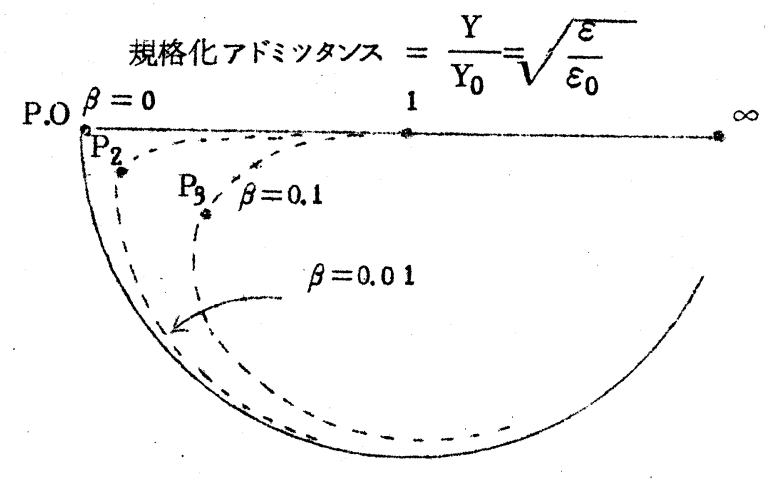

3. 放軋プラズマの測定に於る

反射係数道視装直の利用

理研 坂本雄一、三好炤一

反射係数㨁視装置の二.三の可能性と、当研究空に於ける10GC帯のそれの設計、計画等につ いて報告。 


\title{
(b) ブリッジお上び干涉計
}

\section{Plasmaのmi crowave interferometer 依る測定}

\author{
京都大学理学部田中茂利、高橋、勲
}

\section{$\S 1$. 概 要}

尊波管内に一様なP l a smaがある場合の伀播特性を㭘楌し、その伝播常数からP l a sma の電子密度、衝突周波数を求める式を得た。夷験的には定常的な放電プラズマを導波管に聥入 して、マイクロ波干涉計の方法に依り電子密度を測定し、Lan gmu i r ProkeKよつて測 定した值と比較した。一般淃者の方が数倍火きい値を得るが、これは電子密度の空間分布か ら説明出来る事を示しだ。

\section{§2. 本文}

導波管内に一槏なPla sma がある場合の 1 管内波長 $\lambda \mathrm{g}$ 当りの relative phase shift $\Delta \mathrm{Og}_{\mathrm{g}}$ とat tenuation facter $\alpha \mathrm{g}$ を求めると

$$
\begin{gathered}
\Delta \mathrm{Og}_{\mathrm{g}}=2 \pi\left\{1-\frac{1}{\sqrt{2}} \frac{\lambda \mathrm{g}}{\lambda}\left\{\left(\frac{\lambda}{\lambda \mathrm{g}}\right)^{2}-\frac{\eta}{1+\beta^{2}}\right\}^{1 / 2}\left[1+\left(1+\left(\frac{\eta \beta / 1+\beta^{2}}{\left(\frac{\lambda}{\lambda \mathrm{g}}\right)^{2}-\frac{\eta}{1+\beta^{2}}}\right)^{2}\right\}^{1 / 2}\right]^{1 / 2}\right\} \mathrm{rad} / \lambda \mathrm{g} \\
\alpha \mathrm{g}=\frac{2 \pi}{\sqrt{2}} \frac{\lambda \mathrm{g}}{\lambda}\left\{\left(\frac{\lambda}{\lambda \mathrm{g}}\right)^{2}-\frac{\eta}{1+\beta^{2}}\right\}^{1 / 2}\left[-1+\left\{1+\left(\frac{\eta \beta / 1+\beta^{2}}{\left(\frac{\lambda}{\lambda \mathrm{g}}\right)^{2}-\frac{\eta}{1+\beta^{2}}}\right)^{2}\right\}^{1 / 2}\right]^{1 / 2} \text { nepero } / \lambda \mathrm{g}
\end{gathered}
$$

となる。これを自由空間について求めた B r ownの式と比較すれば同一密度、同一椆波数の場合 のrelative phase shift は導波管内の方が大さ、又cut off 条件も自由空間の 場合 $\eta=1$ であるのに対して $\eta=\left(\frac{\lambda}{\lambda g}\right)^{2}<1$ となる。

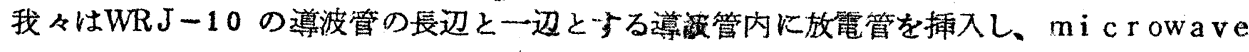
interferometer K依り relative phase shif t を求めて上記の式より電子密 度を求めた。但し電子の衝突周波数レをレ/ $\omega \ll 1$ として $\beta=0$ の近似式を使つた。放電管の封 入ガスはA r (ガス仕 0.5 及び 1 ma Hg $)+\mathrm{Hg}$ 並びにHe $(0.3$ 及び 1 m $\mathrm{Hg}$ ) を使い、放電々 流を0〜300 mAdc の範囲について測定した。電子密度は大凡1 $10^{10} \sim 5 \times 10^{11} \mathrm{~cm}^{-3}$ の範丑 である。 mi crowaveの周波数を9〜10 GC/Sの筑国で変えて測定したが大略同し電子密度 
小島昌治他

を得た。

然るにこれをLangmui r Proke に依る測定値と比較すると常にLangmui r P r oke に依る值の方が数倍大きい。此の差異は電子密度の空間分布を考えれば或程度の説朗はつく。 即ち我々の場合Langmuir Prokeは電子密度の最大值を測定しているが、microー wave 法ではそれの平均值を求めている。依つて電子密度の空間分布を考慮すればマイクロ 波の测定值から電子密度の最大值を求めるには $\left(\frac{\pi}{2}\right)^{3} \approx 4$ を乗する必要がある。斯くすれば マイクロ波に依つて求めた電子密度とLangmu i r P r oke のそれとほぼ一致する。但し上 記の計算には $\left|\nabla \frac{\varepsilon}{\varepsilon_{0}}\right| \lambda \ll 1$ の仮定が必要であり、導波管内の電波伝播では此の条件が成 立しないから 数值上の一致は余り確かではない。

$$
\text { 5. マイクロ波ブリツジルよるプラズマ測定 }
$$

阪大工 久保宇市、犬石䕒雄

micro wave interferometer を用いて放箸プラズマ中を透過したmicro波の 位相变化量と減衰量よりプラズマの電子密度、衝突周波数の測定を行つた。使用周波数は9600 $\mathrm{MC} / \mathrm{S}, モ ー ト ゙ T E_{10}$ である。放電管と mi c r o 波回路との結合は電酳ホーンを用いた。即ち電 磁ホーンを用いることにより放電管を大きくすることが可能となる。ホーンと放電管の距離を離 せば平面波近似による誤差を小さくすることが出来る。又我々の測定範囲では反射波は実験的に わ理論的にも無視出来る。電磁ホーンは利待 12 デシベル、ピラミッド型を用いた。 放電は平行平板電極を用いた空気中の直流放電である。

(1) 直径 $5 \mathrm{~cm} \phi$ 、電極間距維 $18.5 \mathrm{~cm}$ 、電極直径 $3.5 \mathrm{~cm} \phi て ゙ \mathrm{~d}$ ouble probe を入れた放電 管を用い気压 $0.1 \mathrm{mmH}$ （空気）で $10 \mathrm{~mA}$ ～ $50 \mathrm{~mA}$ の放電を行いこの位相量変化から密度を 測定した。

一方 double probe を用いて、求めた電子密度（イオン温度を仮定して）と上記の mi c ro波で直接求めた位相変化量から計算した密度を比較して見るとよく一致することが判 つた。

(2) 直径 $5 \mathrm{~cm} \phi 、$ 電極間距離 $30 \mathrm{~cm}$ 、電極值径 $3.5 \mathrm{~cm}$, single probe 4 ケを插入した

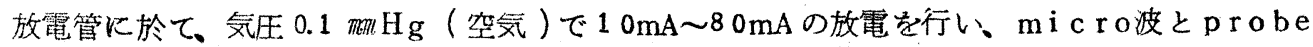
とで同時に電子密度を測定した。 
昭和 3.4 年度ブラズ、測定研究会のまとめ

尚この実験に於ては電磁ホーンの間隔を変え、その各々の場合に就いて測定される量の変化を 調ベた。この場合放電管の位置はホーン間の中央である。この結果間隔が特に小さくない限り ホーン間隔による密度測定値の見掛上の変化は極めて小さかつた。又ホーン間隔を $22 \mathrm{~cm}$ に開 き、その間の種々な位置に放電管を置いて測定値の相異を調べた。この結果ホーンに放電管を 余り近つけると最大 2 倍程度の相異が認められた。(グラフ(2)参照 )

ホーン間隔 $7 \mathrm{~cm}$ の場台に求めた電子密度と $\mathrm{S}$ ing $1 \mathrm{e}$ Probe の電子電流から求めた電子 密度を比較すると 2 倍程 $\mathrm{mi}$ c r o 波に依つて得た方が高く出る。これに就ては p r obe の位置。 表面の状態が考えられ、放電の振動による影響とは考えられない。

以上の実験の結果と理論的計算による検討の結果、使用周波数がプラズマ周波数より、はる かに大きい場合、透過波法を用いて十分確かな測定が出来ると云える。（グラフ(1)参炤）

(3) 我々の実験条件では普通隇衰量变化は測定にか」らなからたここれは衝突周波数から考えて も妥当である。

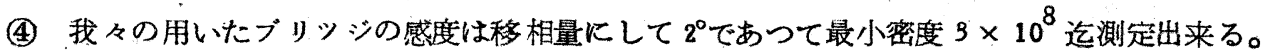

(5)，感度は検出器の $\mathrm{S} / \mathrm{N}$ 比で決をる。
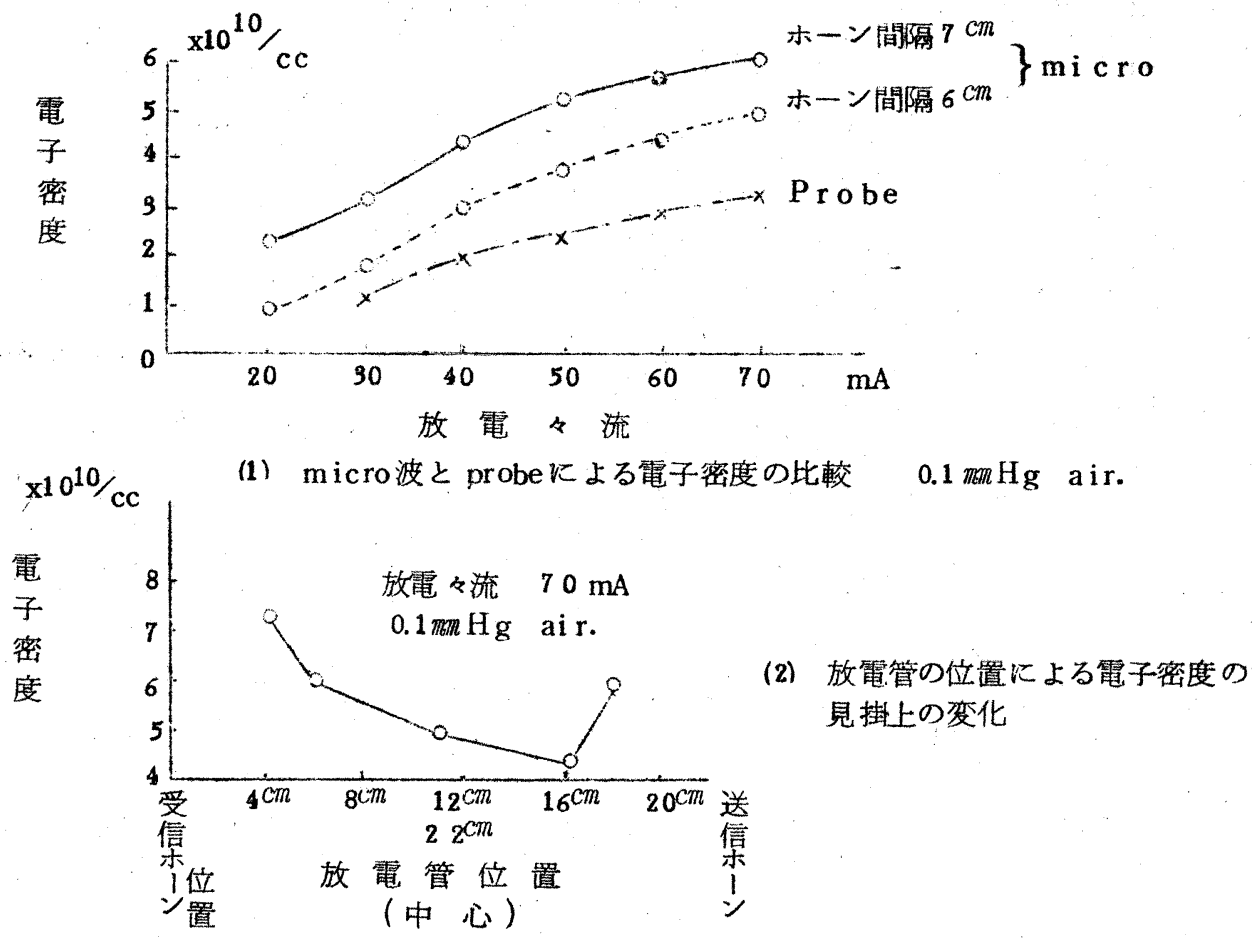
6. マイクロ波ブリツジに依る過度プラズマの電子密度の測定

理研坂本雄一、三好昭一

過渡プラズマの電子密度を波プリッジで測定する際、 t e s t pa t h に於ける反射散乱に基 く ラズマを10 GC带で測定した実験例について報告した。（近く核融合研究誌に発表の予定。）

\section{7.ミリ波によるプラズマ測定}

沖電気研究所

青井三郎、仲矢茂長、林 良一 名古屋大学工学部

田中裕三、赤尾保男、奥田孝美

1. まえがき

山本賢三

現在我が国にある超高温ブラズマの測定には、波長にして3ミリ程度のミリ波が必要とされ、 且つ放㐮はパルス的であり測定もパルス技術となる。しかし現在の電子工学のミリ波技術とし ては短ミリ波を用いて超高温プラズマを測定するのには多くの困難がある。そこで比較的にマ イクロ波技術として開発されている8 8 、、6ミ波を用いて、1 $10^{13} / \mathrm{cm}^{3}$ 程度のプラズマを 測定することを一つの予倩段階として計画した。この程度の定常プラズマの発生装置として、 放電々流 $50 \mathrm{~A}$ 、外部磁場 1000 ガウスを目標としたが、今回の実験ではコイルの製作がをに あわず、磁界を加光ることが出来なかつた。定常電流 15 A で約 $6 \times 10^{12} / \mathrm{cm}$ の密度を得た にとどまつた。しかし 8 ミリ波での位相推移の測定、ならびに隇衰の観測が出来たので、一応 初期の目標は達せられた。更にコイルの組立、カソードの改良、パルス放電、6ミリ波による 測定等を計画実施中である。

2. 装置

放電管は図(1)の如きものである。オキ+イド カソードを使用、アノードはステンレス円筒 を用いた。マイクロ波通過路はフラットな空をつけた。ブローブはマイクロ波通過路に直角に 先端をカソードに向けて直径 $0.3 \mathrm{~mm}$ のモリブデン線を9.8 mm露出しあとはガラスひらくした。

ミリ波回路は図(2)に示す様にブリッシ回路を用いた。位相のずれを較正された移相器により 測定した。15 A 程度の電流では位相補償だけではバランスが補償されず、減衰が認められた。

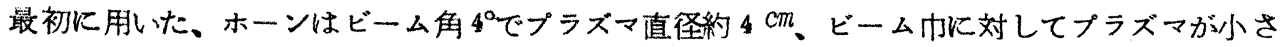




\section{昭和 34 年度プラズマ測定研究会のまとめ}

く、又場所によつて電磁波のプラズマ内でのパス（pa t h ）の長さが異なり誤差の原因となる ので、輻射体として、メタルプレート型のレンズを用いだ。同し開口面積のホーンに比し約 $10 \mathrm{db}$ 利得をあげることが出来た。又凡その測定結果 $2 \sim 3 \mathrm{~cm}$ の直径円内に殆んど $90 \%$ 以 上のエネルギーが集中していることが推定された。尚レンズ開口面は $6 \times 5 \mathrm{~cm} 、$ 焦点距離は $13 \mathrm{~cm}$ である。

3. 実 験

A r.Xe ガスについて種々の気圧のもとに測定した。その結果を図(3)に示す。プローブ測 定は、ブラズマの不安定な振動のため信頼度はよくない。又密度が大になるとプローブの電流 密度大となりプローブが熱的に破壊し測定は不可能となる。プローブ測定值中実線は電子電流 からの算出值であり、e 破線はイオン電流からの算出値である。イオン温度は数百 ${ }^{\circ} \mathrm{K}$ と仮定 した。

以上の事から放電々流 $30 \mathrm{~A}$ 以上、更に酳界を加える事により、1 $0^{14} / \mathrm{cm}^{3}$ ，程度の密度には 達することが予想される。 


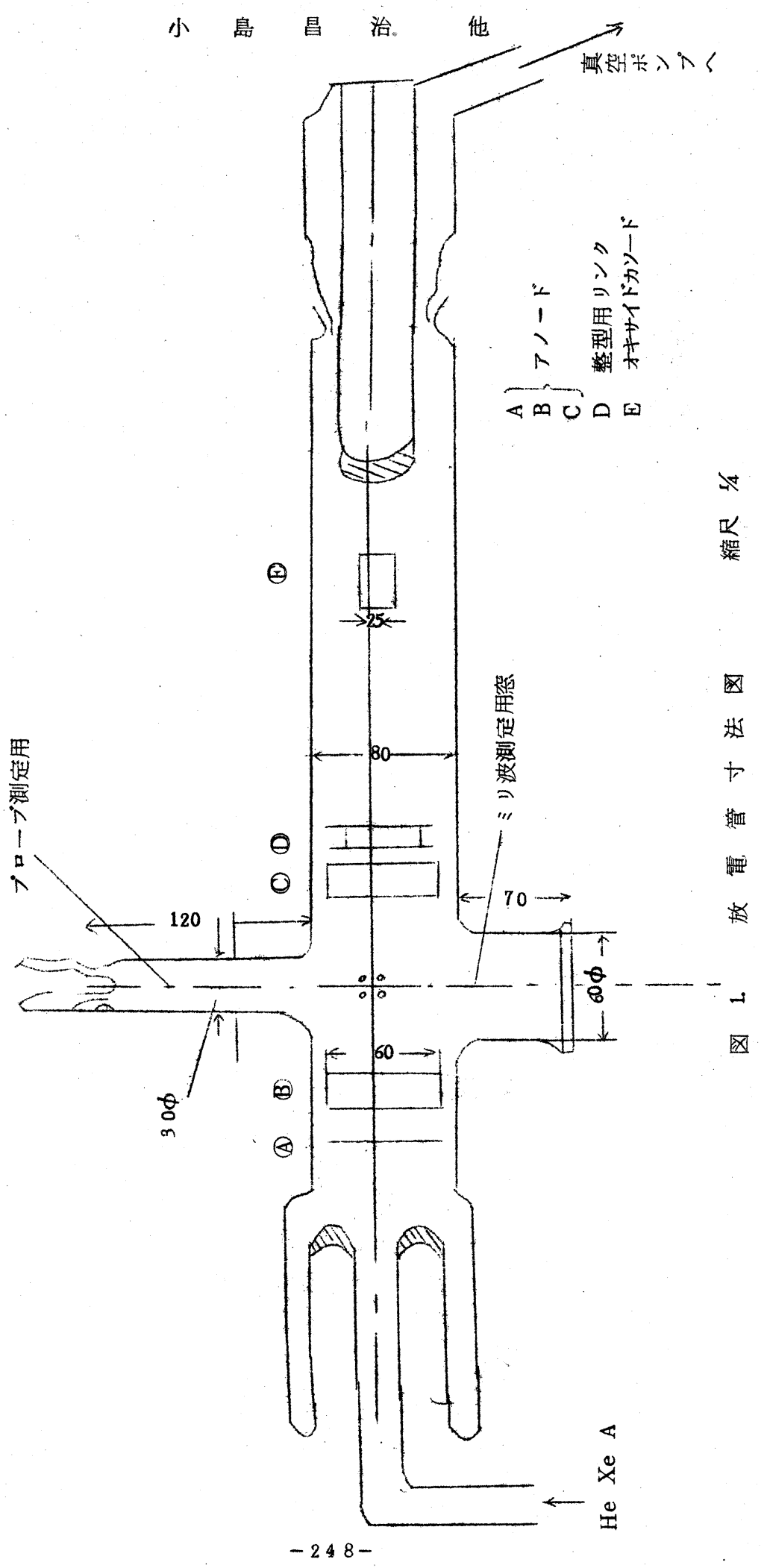


昭和 34 年度ブラベマ沜定研究会のまとめ

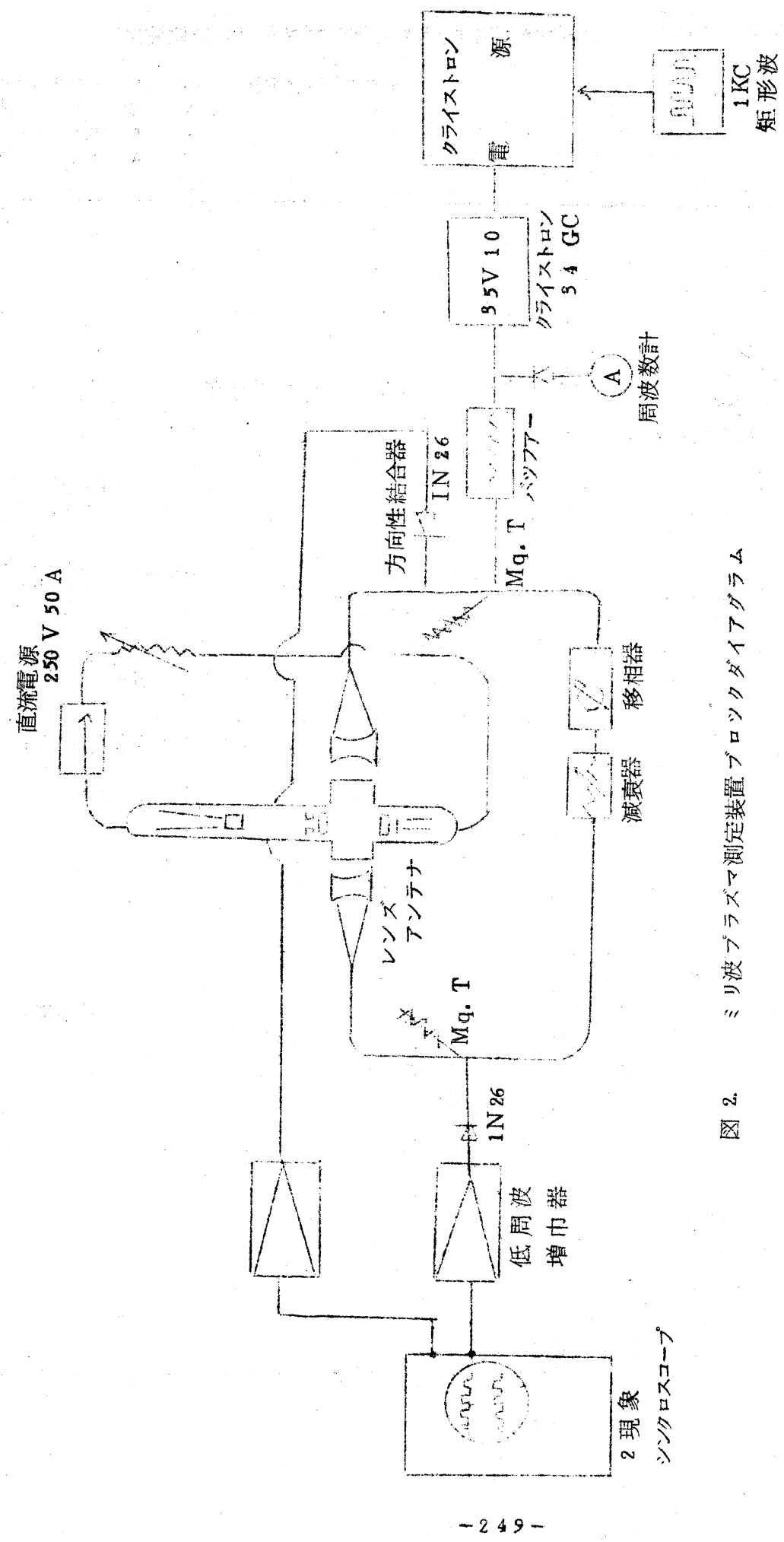


小鳥昌治他

図3. 8.6 ミリ波によるプラズマ密度の测定結果及びプローブとの比慗目

$\begin{array}{llll}\text { マイク皮定值中 } & \Delta & \mathrm{Xe} & 0.12 \mathrm{mmHg} \\ & \times & \mathrm{Xe} & 0.052 \mathrm{mmH} \\ & & \mathrm{Ar} & 0.36 \mathrm{mmHg} \\ & \square & \mathrm{Ar} & 0.052 \mathrm{mmHg}\end{array}$

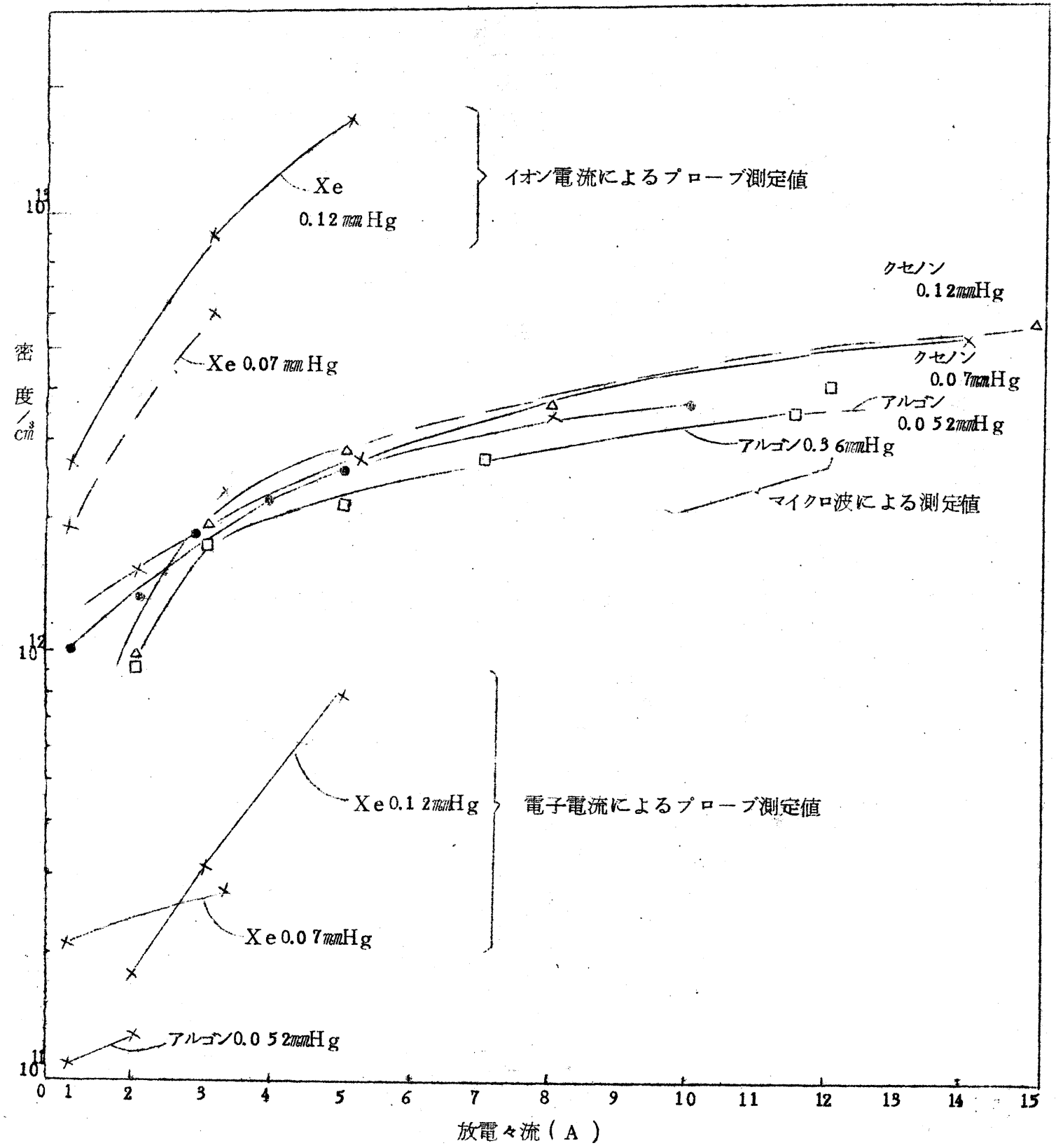


8. $35000 \mathrm{MC}$ マイクロ波干涉計による電子密度の測定

$$
\text { 日大中田順治 }
$$

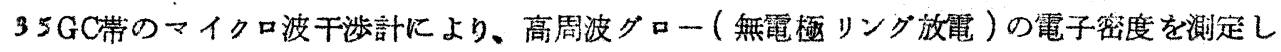

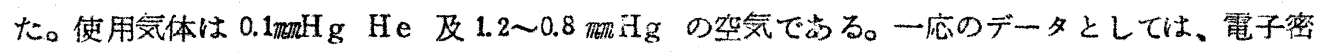
度は放電々力と共に直線的に增大し $500 \mathrm{w}$ 程度で、He では $7 \times 10^{\prime \prime}$ ケ/cc. 空気では4 10 ○ヶ/cc. の值が得られた。管の軸方向にそつて測つた場合と、直堡方向にそつて㵋定した 場合では放電状態が同一でも得られる值に相当な開きがあり、放電管の軸方向分布では、中央程 密度の高いことを示している。

干政計を使用する際注意すべき点として、電波ビームの桩がりと、放電管の大きさの関係及び その間の整合の問題、機械的振動を防ぐこと等が上げられる。

（c）雑音測定およびラジオメーター

9. コンデンサー放電の雑音測定

理研坂本雄一、三好昭一

$10 \mathrm{GC}$ 帯電界強度測定器を用い500WV $10 \%$ F 電解コンデンサーバンクによる值線状放電プラ ズマの熱雑音を測定 $\mathrm{Te}=2 \times 10^{4}{ }^{\circ} \mathrm{K}$ を得た。

$$
\mathrm{I}_{\mathrm{max}}=16 \mathrm{ka}, \mathrm{BZ}=0 \text {, 空気約 } 0.1 \mathrm{r} \mathrm{Hg}
$$

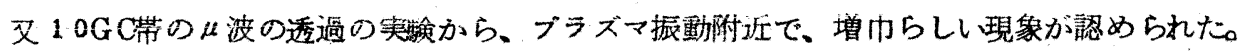

10. プラズマの雑音測定

東京教育大学

小島昌治、加藤清江、萩原茂男

測定するマイクロウエーブの周波数 $\mathrm{f}$ がプラズマの笔子密度に関するプラズマ振動の周波数 $\mathrm{f}_{\mathrm{p}}$ より大きいとき $\left(\mathbf{f}>\mathbf{f}_{\mathrm{p}}\right)$ ，その周波数に対してはプラズマはいわゆる不透明ではなくなり。 Brems s t rah rungによる輻射が入つて来る。この場合プラズマは輻射平衡になつていると はいえないので注意を要する。 
小島昌治他

この点を確かめる意味で各電子密度に対して、プラズマの厚みの影響をしらべた。その結果、 輻射平衡に達する電子密度即ち放電々流は $10000 \mathrm{MC}$ と $3000 \mathrm{MC}$ とでは明らかに相違し、 $\mathrm{f}_{\mathrm{p}} / \mathrm{f}=1$ の附近にその臨界点がある様に思われる。

又螢光燈の熱雑音を電磁ホーンで測定してみると、標準雑音源から得たすのと比較してほぶ满 足すべき結果が得られた。

\section{1. 磁場中のプラズマのマイクロ波雑音測定}

\section{京大教養部}

三谷健次、久保 熙。西尾昭男

§ 1. マイクロ波雑音測定の概要

プラズマから、種々の機桡によつてマイクロ波雑音が輻射され、これを測定することによ つて、プラズマの重要な情報を得ることが出来る。(1)マイクロ波雑音を測定する装置は mi c r o wave radiome t e r ${ }^{(2)}$ と称せられる。吾々は今回これを試作し、その性能をテストすると 共に、磁場中のプラズマから輻射される雑音を試験的に測定したので、その結果を簡単に報告 ナる。

プラズマが密で、プラズマとアンテナ系とが熱平衡にあり、インピーダンス整鸽が取れてい るならば、平面偏波に対し、装置の受取る電力 $\mathrm{P} は$ 次の式で与えられる。即ち

$$
\mathrm{P}=\mathrm{k} \text { Te B }
$$

こなに $\mathrm{k}$ はボルッマン定数、Teはプラズマの電子密度、Bは受信機の帯域巾である。

プラズマから輻射される雑音には上記のような熱雑音の外に、プラズマが磁場中にある時の サイクロトロン輻射や r unaway e lectron，が出す制動輻射のようなるのがある。此等 は熱的輻射ではないから、(1)のよな式で温度を求めるという事は無意味であることは云うま でもない。

§2. 装置及び放電管

マイクロ波雑音測定にはsuperheterodyne 形式が用いられる。Fig.1は吾々の 試作した装置の全体図で、局部発振周波数は10KMCである。 
I. F. Amp の詳細は略す。豆中心周波数は $25 \mathrm{MC}$ パンド巾 $5 \mathrm{MC}$, 利得はP r e a mp b含めて約 $90 \mathrm{~d}$ bである。

本装置を用いるにはma gi c T e e 両端のプ ランジャー及びスタプを用いて local osci1 later noi seを最小にする。 a rm の整合は鋭敏であるから、この部分の整 合を充分に取ら孙ばならない。

吾々の用いた放電管は内径 $9.2 \mathrm{~mm}$ 、長さ $30 \mathrm{~cm}$ の熱陰極放電管で、1.9 mm H g のアルジンを封 入した。ガラスによるマイクロ波の吸収を出来 る丈小さくする為、新日本電気ガラス製の特殊 ガラスを用いた。又此の実験ではアンテナ系を 用いる代りに、この放電管を導波管に $10^{\circ}$ の 傾きをなして挿入された t emperature active plasmaを用いた。

§3. 測定並びに結果の吟味

先ず輻射されるnoise l evel の放電 電流に対する変化を測つた所Fig.2.の様にな り、放電々流にほら゙無関係となつた。吸収測定 の時は放電々流が太さいと電子密度が大きく。 従つて吸収す大きくなる為、放電々流を $30 \mathrm{~mA}$ 乃至 $40 \mathrm{~m} \mathrm{~A}$ まで下げて測定した。

Fig. 2. マイクロ波ノイズの 放電 々流特性
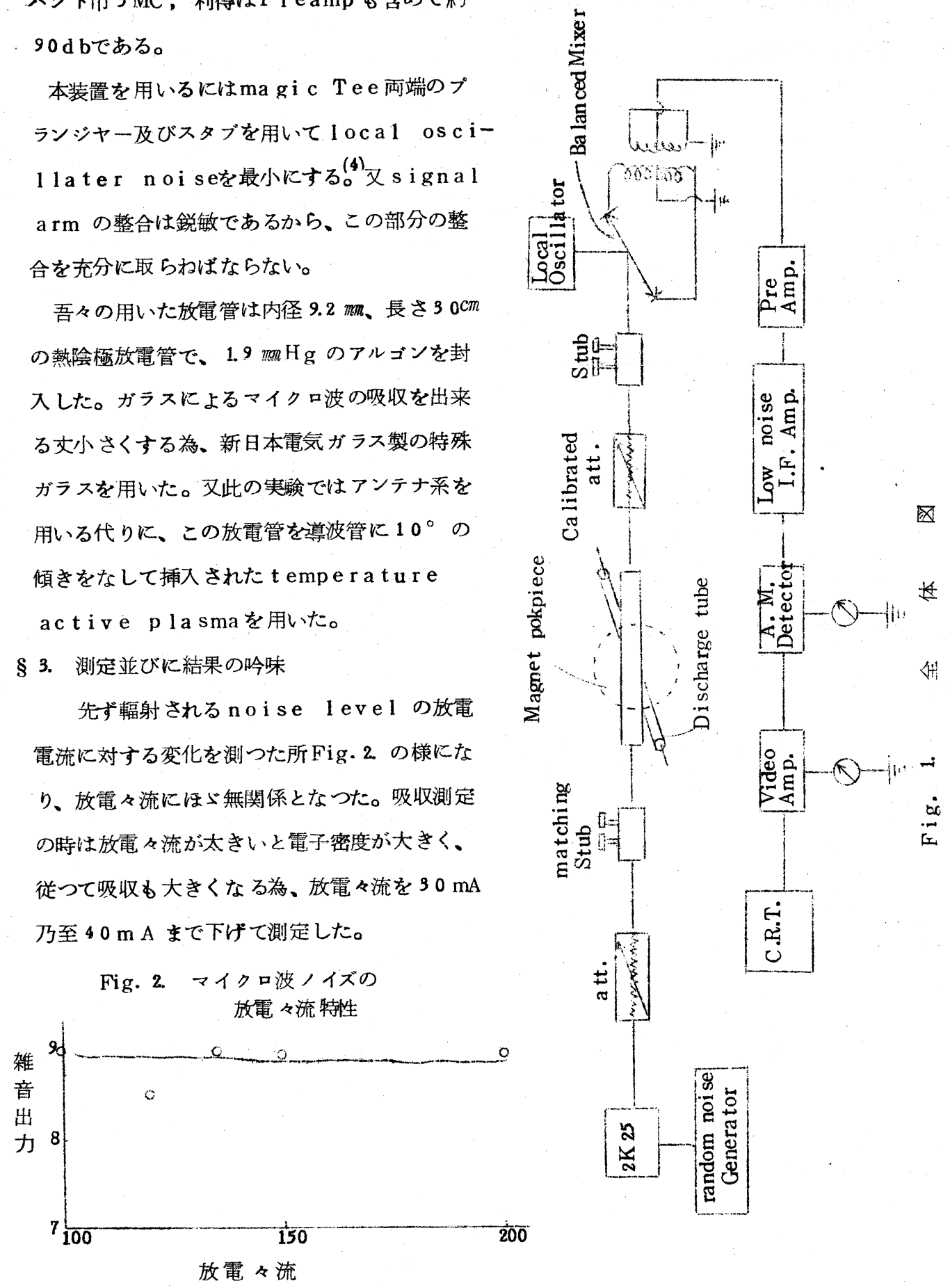
小島昌治他

次に磁場に対する影響は 磁場をマイク口波の進行方向に垂直に、而もそのEベクトルにも 垂渞になる様にプラズマに加えて調べた。

Fig. 3. は cyclotron reson ance radiation の実験結果である。これは 大体Heit ler の式

$$
I(\omega)=I_{0} \frac{2 \nu_{c}}{\pi} \frac{1}{\left(\omega-\omega_{c}\right)^{2}+\left(2 \nu_{c}\right)^{2}}
$$

と一致する。これによる半值巾と夷験值との此較から、collis i on frequency $\nu_{c}$ として。

$$
\nu_{\mathrm{c}}=5.6 \times 10^{8} \mathrm{sec}^{-1}
$$

が得られる。

Fig.4は磁場が作用する場合の t r ansmission の実験結果である。これは C. B. Wharton の式 ${ }^{(1)}$

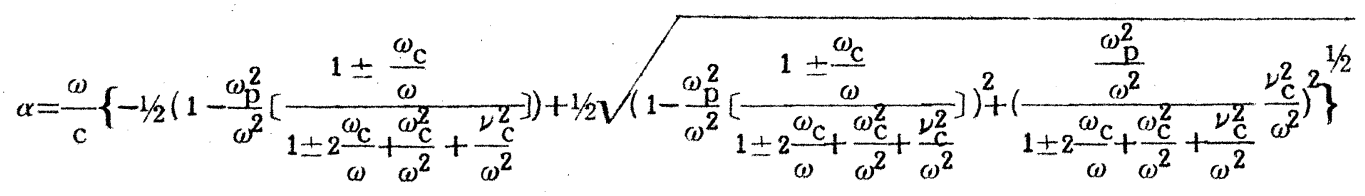

と比較される可きものであるが（9が正しいとすれば $\nu_{\mathrm{c}} / \omega<1$ となり、この条件での(4) の爾值は

$$
\omega_{\mathrm{p}}^{2}=\omega^{2}\left(1-\frac{\omega_{\mathrm{c}}}{\omega}\right)
$$

で与えられる。吾々の実験 Fig.(4では、この極值を与えるHは3100 gaus s であるから、 これを用いて(5)から電子密度 $\mathrm{n}$ を求めると

$$
\mathrm{n}=1.36 \times 10^{11} \mathrm{~cm}^{-3}
$$

(3)(6)の值は一応妥当な值と考える事が出来る。

\section{$\S 4$. 結 語}

以上で吾々は一応の結果が得られたが、尚装置に改良を加えて精度を上げ、理論との比較 を厳密に行らと共に、より高範囲に亘つてプラズマの諸特性を測る予定である。 
昭和 34 年度プラズマ测定研究会のまとめ
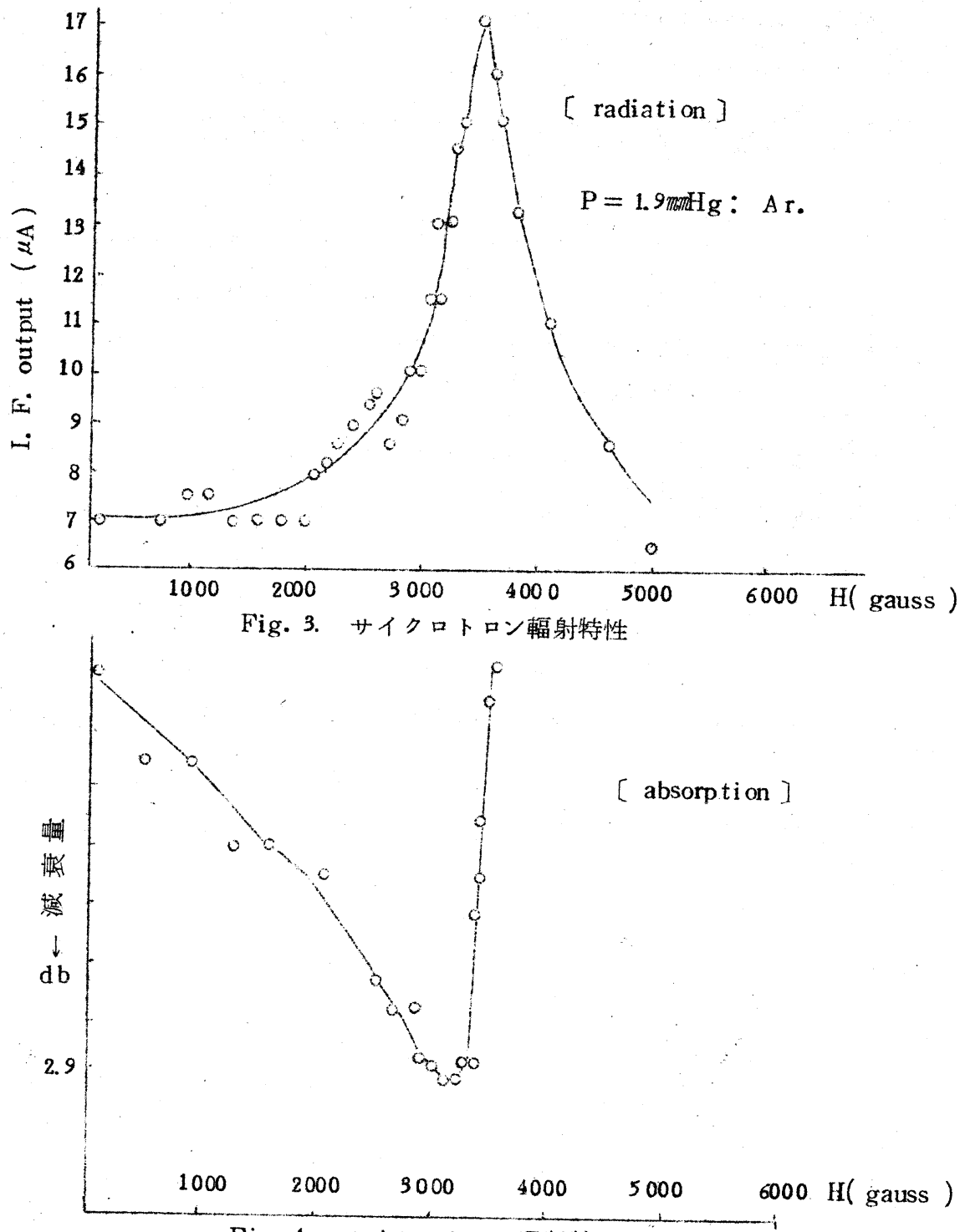

Fig. 4. サイクロトロン吸収特性

文献

(1) C. B. Wharton: UCRL 4836

(2) C. B. Wharton: UCRL 5129

(3) C. E. Edwards: I.R. E. . (1947) P. 1181 参照

(4) R. V. Pound : Micr owave Mixer(M. I. T. Radiation Laboratory Series, McGrow-Hi 11,1948) 
小島昌治他

(d) その 他

12. プラズマに関する実験的研究

東大、工学部

関口忠、塩原信司、一丸節夫

宮本俊樹、飯田広幸、山崎浩

a ）熱伝導現象及びエネルギー緩和時間の実測

荷電粒子密度 $1 d^{1} \sim 10^{12} \mathrm{~cm}^{-3}$, 電子温度 $1000^{\circ} \mathrm{K}$ 以下のネオン、ヘリウム及びクセノン プ ラズマに対しアフターグローブラズマを利用して熱伀導度を実測した。実験手段としては、マイ クロ波パルスをブラズマ定数の測定及びプラズマ中の電子ガスの選択加熱のために利用し、一方 電子温安の変化は二次電子堌倍管を用い、プラズマよりの輻射光量の変化より検知した。電子ガ スの熱伀導率は"定常法"及び "過渡法"と呼ら二つの独立な方法で決定し、両者による実測結 果は上く一致した。そしてその大きさは上述の柆子密度、電子温度範用で $10^{-6} \sim 10^{-5}$ (ワット $c m$, 度 ) 程度の大きさであることが判明した。さらに実測したプラズマの電離度は $10^{-5}$ 以下の 非常に小さいものであるにも不拘、熱伝導率の実測值はS p i t ze r 等の理論值と可成りよく一 致すること、又熱伝導率は電子温度によつては遥やかに変化するが、電子温度によつては $5 / 2$ 乗に比例して急激に増大することが上記の測定範囲内で確かめられた。以上の実測結果より結論 として、プラズマ中の熱伝導現象には電子一電子間のクーロン相互作用が主導的な役割を果すこ とが判明した。

尚、本研究の過程中、電子ガスとイオン及び中性原子ガス間のエネルギーに対する緩和の間題 も実験的に究明する必要があつたので、附則的にその実测も行い上記の测定箸囲内で数 $\mu$ 秒程 度の緩和時間を観測した。

今後の問題点として、以上の熱伝導及びエネルギ一緩和現象をより一般的な場合、即ち磁界が 加わつている場合、荷電粒子密度及び温度がより高くなつた高温高密度プラズマの場合、更に電 子温度ばかりでなくイオン温度にも位置的に温度勾配がある場合等に拻張することが緊要である。

<発表文献>

(1) Phys. Rev., 109, 625 (1958), (2) Phys. Rev., 112, 1 (1958)

（3）電気学会雑誌，79，60.854，pp. 32-41（昭34年11月），(6) 核融合研究，(昭34年 7 月号） 
昭和 34 年度ブラズマ測定研究会のまとめ

b) 磁界中のプラズマ拡散

将来の核融合の成否を支配する重要基本課頙の一つに、磁界中のプラズマ粒子茠失機構解明の 問題がある。この機構にも種々のものが考えられるが、本研究はその为一段階として粒子間衝突 による桩散 (Collisional diffusion) と、いわゆる"Drain diffusion" (プラズマ中の擾乱電界と磁界による粒子のドリフトに基つく拡散 )とを、従来とは異なる新し い実験方法によつて分離、実測し、その機構を究明することを目的とする。

実験方法は、(1)直径約 6 mm、長さ $120 \mathrm{~cm}$ の非常に練長いガラス放電管に水素、ヘリウム及び ネオン等のアフターグロープラズマを作り、その軸方向に最高5,000ガウス程度までの直流磁界 を印加し、(2)マイクロ波及び二次電子增倍管に上る光量測定を手段として、アフターグロ一中の 荷電粒子密度の時間的減衰より滋界を横切る粒子の拡散係数を測定する。現在ここれに対する才 一段階の理論的考察を終了し、実験続行中である。

<発表文献>

磁界中に於ける気体プラズマの拡散（電気学会東京支部大会予稿、28,昭 34 年 11 月）

c）イオン、サイクロトロン共振加熱機構

イオン、サイクロトロン共振によるプラズマ加熱機構を調べるための矛一段階として、小型整 陰極放電管に平行平面電極を封入したものを試作、噁界 3,000 ガウス程度での実験を進めている。 供試気体は現在の所、水素で、高周波電界の周波数は約 $3 \mathrm{MC}$, 印加電力は 300 ワット程度。測 定は二次電子增倍管による光量測定及び高周波回路への反作用の測定によつて行なう。

d）ブラズマ駆動用進行波酳界発生回路

プラズマを直線状に駆動して衝撃波を得るための一つの方法として、へッックス伝送線路に衝 撃進行波電流を流し、それが作る進行波磁界を利用することが考れられる。現在はその为一段階

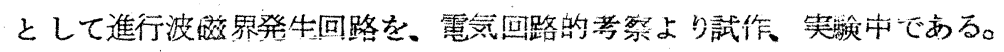

\section{3. マイクロ波による衝撃波高温プラズマの浿定}

京大教䉵 竹山乵夫

広大理浜村司郎、尾田年充

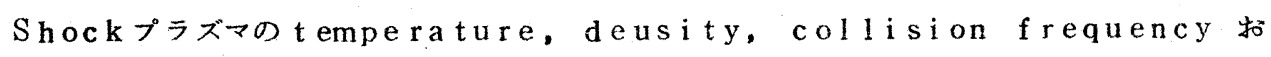
よび、速度等を測定するために、マイク口波を用いる研究は最近各所で行われつつあり、流行の きさしがある。吾々のところでは、薄膜によるshock波プラズマについて、マイクロ波立体回 
小島昌治他

路觉そのままshock tubeとして用い,shock front からのマイク口波の反射。よ び吸収そ測定し、又光学的な測定を併用して、s hock プラズマの速度、電子密度扣よび、構造 を求めることを目的として実験を行つた。現在のところ、定性的な結果として、s h ock プラズ マが出来て行く過程、および速度、又shockが t ube の終端に達したとき、reflected shock wave とincident shock wave が干啮し高温になるとともに独特の構造 があること、等の観測をすることが出来た。 度の長さを有し密度分布の变化は壁のところでは線型にかわり、年々の実験ではプラズマは矩 形導波管の中に矩形的に閉じこめられたことになり、マイクロ波でイムピーダンスの測定をする とき、実験は単純化される。この点に着目して、プラズマによるマイク波の反射吸収をより正 確に測定して定量的な結果を得ようとしている。又Caltech のR.G Jahnは shock $\mathrm{t} u$ be に対して直角方向から、ホーンにより測定を行い上記 $\mathrm{t} u$ be の終端に出来た高温プラ ズマの電子密度等を測定しょらとしている。(2)(3) イギリスのTeddington $\mathrm{Na}$ t i ona 1 Physical Rab. では同様実験をsub-mil1imeter の beam で行括うとしてる。 又Israelのへブライ大学のDr. Manheimer は波長 $3 \mathrm{~cm}$ で円形の $\mathrm{shock}$ tube 中 にマイク口波を入れて終端ブラズマの電子密度を定䁷的に測定している。

(1) M. Takeyama, S. Hamamura and T. Oda ; J. Phys Soc. Japan 14, (1959) 1697

(2) R. G. Jahn and F. A. Gross ; Technical Report *6. 13. NR.061-063 (1958)

(4) Y. Manheime r

" 6. 9. AF. $603 \sim 2(1959)$

; ヘブライ大学紀要 (1958)

\section{4. 密度測定にお壮る電磁ホーンの影響}

$$
\text { 同志社大工 谷口- 郎 }
$$

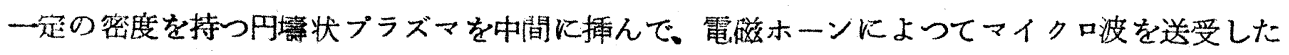

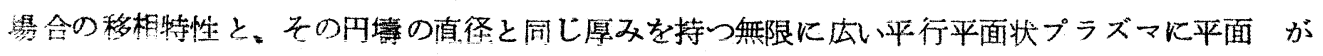
透過した場合の移相特性との差異を密度をパラメータとして近似的に計算した。

計算法としては光学レンズの設計で用いる三角追跡法を用いた。まず送信側と受信側のホーン の開口面を $\mathrm{n}$ 等分し、その $\mathrm{n} コ$ コ中心点を各自両側で対応させて、合計 $\mathrm{n}^{2}$ 本の行路を計算した。 つぎにこれら $n^{2}$ 個のベクトルに開口面の各点の振巾係数、指向特性および各行路の透過係数 


\section{昭和 34 年度プラズマ測定研究会のまとめ}

乗じて加え合せ、全行路差を得た。

計算は主として現在京大で計画している6 man用のホーンの設計值（開口面 $2.5 \times 2.1 \mathrm{~cm}^{2}$ )を用い: プラズマの直径としては4 cmを仮定した。計算過程において $\mathrm{n}=1 ， 3 ， 5$ と順次近似度を高め たが、この程度のものとしては $\mathrm{n}=5$ で充分と考えられる。以上の結果から、最初に述べた二つ の仮定の相異から出る誤差は、密度の誤差としてせいぜい2３％、円擣状プラズマの中心が、 両方のホーンの中心を結ら線から約 1 cmずれた場合でも数\%以内であるとの結論を得た。

以上の考察は反射の影響は全然考慮していないが、内部反射の影響は完全な平面波を用いた場 合よりむしろ軽滅されると考えられる。

その他の結論としてホーンの開口面の大いさは対象とするプラズマの大いさよりも大きくては ならないこと、また外部反射は最も大きな閥題となるので、プラズマを透過するくりいはでをる だけ大きいことが望ましいが、ホーンをあまり近づけると一次霓界が反射などによつて乱される 等である。

\section{5. 電子のサイクロトロン共鳴}

教育大

小皂昌治、加藤清汇、萩原姿男

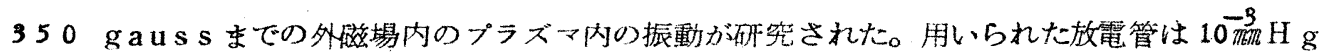
の order の圧力の水銀蒸気で满された熱陰極放電管である。外诿場は放電電流と同方向に一ル ムホルッ・コイルでかけられ、その強さはプロトン共鳴で目盛を定められたフラックスメーター で測定された。振動は一定の周波数に㺃節された超再生受信機で検出された。として振動の強度 を縦軸に磁場の強さを㮠軸にしてブラウン管上で直接目で兒られるようにした。

実験の結果として放電電流に関係なく周波数がきまれば外磁場の强さを一定のところであらわ れる振動と、周波数をさめても放電電流をかえると外烈場の強さをそれに合せて適当に選ばなけ れば検出出来ない振動とがあることが分つた。前者が笔子のサイクロトロン共鳴による振動と思 われる、後者は傢場内のブラズマ振動かと思われる。

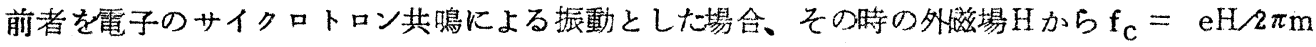
によつて計算された周波数はそのHで測定した周波数より大きい。そのらがいの原因を全部プラ ズマのデイアマグによるものとすれば数\%の反磁性があることになる。その値は理論的烤えら れる反磁性よりも大きな值である。 
小島昌治他

またサイクロトロン共鳴振 重:の半值巾も測定された。その一例をあげれば７００MCの共鳴周波

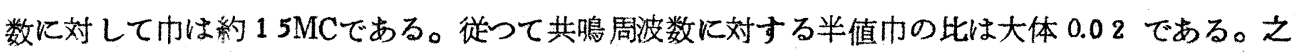
は合理的な值である。 